\title{
Savaşın Öteki Yüzü: Romanya'daki 93 Harbi Esirleri
}

\author{
Naim Ürkmez*
}

\section{$\ddot{O}_{z}$}

93 Harbi olarak adlandırılan 1877-1878 Osmanlı-Rus Harbi’nde Rusların 10 Aralık 1877'de Plevne'yi ele geçirmesinden sonra 40.000 civarındaki Osmanlı askeri Ruslara esir düşmüştü. Bu esirlerin yaklaşık 30.000’i ağır kış koşulları altında Rusya’ya götürülmüştü. Kalan 10.000 esir ise, savaşa Osmanlı Devleti'ne karşı Ruslarla ittifak ederek giren Romanya'ya bırakılmıştı. Bu çalışmada Plevne'de esir edildikten sonra Bükreş'e sevk edilen askerlerin hazin hikâyesi anlatılmıştır. Esirlerin hangi koşullarda Bükreş'e sevk edildiği ve bu şehirde ne surette yaşamlarını idame ettikleri betimlenmiştir. Siyasî tarihten daha ziyade insan merkezli olacak bu çalışmada esir düşen askerlerin gözünden, savaşın bilançosu ve sebep olduğu acılar tasvir edilmiştir.

Bu savaşta Rusya'nın tarafinda yer alarak Osmanlıya karşı mücadele eden Romanya, Berlin Antlaşması ile bağımsızlığını kazanmıştı. Ancak Besarabya’yı Rusya’ya kaptırmıştı. Bu sebeple savaştan sonra Ruslara karşı mesafeli duran Romanya hükümeti, elindeki esirleri de vasıta ederek Osmanlı Devleti ile ortak düşmana karşı işbirliği içerisine girme eğilimi içerisine girmişti. Bu süreç boyunca Rumen yetkililer, Türk esirlere olabildiğince iyi bir şekilde muamele etmiştir. Netice itibariyle Osmanlı Devleti ile Romanya arasında yapılan esir iade mukavelesi imzalanmıştı. Bu mukavele, Romanya Devleti'nin tanınması açısından oldukça önemliydi. İlk diplomatik temasların bu surette kurulmasindan sonra Romanya ile Osmanlı Devleti arasinda olan ilişkiler hız kazanmış, karşılıklı olarak diplomatik temsilcilikler ihdas edilmiştir. Netice itibariyle iki taraf arasında güvene dayalı bir siyaset başlamıştı. Romanya, özellikle Osmanlı Devleti tarafindan tanınmasını önemsemiş, Osmanlı Devleti ise yeni kurulan devletin, Ruslarla arasına bir set çekeceğini düşünmüştü.

Anahtar Kelimeler: Plevne, Romanya, Bükreş, Türk Esirler, 1877-1878 Osmanl-Rus Harbi.

* Doç. Dr., Erzurum Teknik Üniversitesi, Edebiyat Fakültesi, Tarih Bölümü, Erzurum/ TÜRKIYE, naimurkmez@erzurum.edu.tr ORGID: 0000-0002-3186-8350 DOI:

Makale Gönderim Tarihi: 01.08.2019 - Makale Kabul Tarihi: 09.01.2020 


\title{
Other Face of the War: Prisoners of the Ottoman-Russian War of 1877-1878 in Romania
}

\begin{abstract}
In the Ottoman-Russian War in 1877-1878 (Russo-Turkish War, also called 93 Harbi in Turkish), around 40.000 Ottoman soldiers were taken prisoners after the Russians captured Pleven on 10 December 1877. About 30.000 of these prisoners were taken to Russia under severe winter conditions. The remaining 10.000 prisoners were left in Romania, which entered the war in alliance with the Russians against the Ottoman Empire. In this study, the sad story of the soldiers who were taken as prisoners to Bucharest after being captured in Pleven is told. This study depicts the conditions of the prisoners who were sent to Bucharest and how they continued to live on in exile. This study, which is rather human-centered than political history, portrays the consequences of the war and sufferings caused by the war from the eyes of the exiled soldiers.

Romania, which takes sides with Russia in the war against the Ottoman Empire, gained its independence with the Berlin Treaty. But Romania lost Bessarabia to Russia. For this reason, the Romanian government, which remained distant to the Russians after the war, began to cooperate with the Ottoman Empire and against the common enemy. During this period, the Romanian authorities treated Turkish prisoners as well as possible. After all, the Ottoman Empire and Romania signed a prisoner exchange agreement. This agreement was vital for the recognition of the Romanian State. After the first diplomatic contacts were settled, the relations between Romania and the Ottoman Empire gained momentum, and diplomatic representatives were established mutually. As a result, this set a political environment that is based on mutual respect and trust between the two sides. Romania gave importance to international recognition, especially by the Ottoman Empire, while the Ottomans thought that the newly established state could build a barrier against the Russians.
\end{abstract}

Keywords: Pleven, Romania, Bucharest, Turkish Prisoners, 1877-1878 OttomanRussian War. 


\section{Giriş}

Sultan II. Abdülhamid 1876 yllında tahta çıktığında, Osmanlı Devleti'ni tehdit eden büyük sorunlarla karşı karşıya kalmıştı. Bunların arasında, yabancı devletlerden alınan borçların ödenme(me)si meselesi ve Rusya'nın Osmanlı Devleti'ne karşı girişmiş olduğu siyaset sonrası Balkanlarda ortaya çıkan karışıklıklar en önde yer almaktaydı. Bunu firsata çevirmeye çalışan büyük devletler, Osmanlı Devleti'ne karşı müdahalede bulunma kararı almıştı. Bu müdahalelere engel olmak isteyen Osmanlı ricali, Sultana, Kanun-ı Esasî̀yi ilan ettirmişlerdi. Fakat bundan bir sonuç alınamamıştı. Meclisin açılmasından sonra büyük devletlerle yapılan müzakerelerden netice elde edilemeyince, Osmanlı Devleti, Rusya karşısında yalnız kalmıştı. 24 Nisan 1877 tarihinde Osmanlı Devleti'ne savaş ilan eden Rusya, Karadeniz'in kuzey batısı ve kuzey doğusundan taarruza geçmişti. Osmanlı Devleti'nin Memleketeyn (Eflak-Boğdan) olarak adlandırdığı Romanya üzerinden ilerleyip Şıpka Geçidi'ni aşan Rus birlikleri, 19 Temmuz 1877'de Plevne'de Vidin kuvvetleri komutanı Osman Paşa tarafindan durdurulabilmişti. Osman Paşa komutasındaki birlikler, Rusları burada ancak 6-7 ay gibi bir süre durdurmayı başarabilmişlerdi. ${ }^{1}$

Çarlık Rusya'sı, Osmanlı Devleti'ne savaş ilan etmeden önce, Romanya topraklarından askerlerini geçirmek için, başlangıçta tarafsızlı̆̆ını ilan etmiş olan Romanya yönetiminden gerekli izinleri almıştı. Daha doğrusu Romanya ile gizli bir anlaşma yapmıştı. Gizli anlaşmaya göre Rusya, Romanya'nın bağımsızlığını onaylamakla beraber bu hususta uluslararası sahada Romanya'yı destekleyecek, Romanya'nın kraliyet olması için çaba sarf edecek, Dobruca'nın bir kısmının Romanya'ya ilhakını temin edecekti. Son olarak da savaştan sonra Romanya'nın malı olmak üzere Rumen ordusunu silahlandırmak için tüfek verecekti. Romanya da buna karşılık Rusya'dan taraf olarak Osmanlı Devleti'ne savaş ilan edeceğini, Ruslarla birlikte hareket etmek üzere 50.000 asker hazırlayacağını, Rus askerinin Romanya'dan geçmesine müsaade edeceğini taahhüt etmişti. ${ }^{2}$

Romanya bu anlaşmadan sonra Osmanlı Devleti aleyhine savaşa taraf olmuş, ardından yaklaşık 60.000 askerini Tuna Nehri kıyısına konuşlandırmışı. 9 Mayıs 1877 tarihinde bağımsızlı̆ını deklare eden Romanya, 12 Mayıs 1877 tarihinde

1 Mihai Maxim, "Romanya", Diyanet İslam Ansiklopedisi (DİA), XXXV, İstanbul 2008, s. 170.

2 Basiret, 28 Mart 1294, Sacit Uğuz, Basiret Gazetesi’ne Göre 93 Harbi’nde Rumeli (1877-1878), Atatürk Üniversitesi Sosyal Bilimler Enstitüsü, Yayınlanmamış Yüksek Lisans Tezi, Erzurum 2003, s. 203. 
de Osmanlı Devleti'ne savaş ilan etmişti. ${ }^{3}$ Bundan sonraki süreçte oldukça kritik bir rol üstlenen Romanya, Plevne harekâtı sırasında Rusların Osmanlı Devleti'ne karşı galip gelmesine ciddi katkı sağlamıştı. ${ }^{4}$

Bu çalışmada, 1877-1878 Osmanl-Rus Harbi'nin cereyan ettiği Tuna Cephesi’ndeki Plevne'de esir düşüp Romanya'ya sevk edilen 10.000 civarında askerin serüveni, mevcut kaynaklar ekseninde anlatılacaktır. Askerî tarihin strateji ve taktiği öne çıkaran yönünden ziyade insanı merkeze alan bu çalışmada, esir düşen askerlerin gözünden, savaşın bilançosu ve sebep olduğu acılar tasvir edilecektir. Esirlerin düşünce dünyası, kültür ve inançlarından kaynaklanan insanî meziyetleri betimlenecektir. Esirlerin Romanya'da bulunmasını Osmanlı Devleti ile Romanya arasında diplomatik ilişkilerin şekillenmesinde nasıl etki ettiği ortaya konacaktır.

Çalışma hazırlanırken Osmanlı Arşivi ana kaynak olarak kullanılmıştır. Bunun yanında dönemin gazetelerinden Tercüman-ı Hakikat ve Vakit taranarak esirlerin durumu ile ilgili haberlerden faydalanılmıştır. Aynı zamanda esirlerin Bükreş'te bulundukları sırada onlarla görüşme firsatı yakalamış seyyahların eserlerinden ve devri tasvir eden yabancı basına ait gravür ve tablolardan istifade edilmiştir.

\section{Plevne'de Başlayan Esaret}

Romanya'dan destek alan Ruslar, Plevne'deki muhasarayı şiddetlendirmişti. Osman Paşa, 10 Aralık 1877'de muhasarayı yarma hareketine girişmiş, ancak bu sırada yaralanarak esir düşmüştü. Paşa'nın Rusların eline geçmesinden sonra, Plevne'deki Osmanlı askerleri de Ruslar tarafından esir alınmıştı. Üzerlerindeki yiyecek ve eşyaları, Rus askerleri tarafindan yağmalanan Türk askerleri, aç ve biçare bir surette düzene konulup sevk edilecekleri günü vakur bir şekilde beklemekteydi. Bu beş, altı günlük süre zarfinda yağmakta olan kar ve yağmurun altında kalan ve zaten uzun bir süredir zor şartlarda Plevne'yi savunan bu askerlerin üçte biri açlık ve soğuktan dolayı hayatını kaybetmişti. ${ }^{5}$ Askerlere ancak yedi gün sonra yiyecek vermeye başlayan Ruslar, yiyeceğin miktarını da oldukça kısıtlamışlardı. Askerler,

3 Togay Şeçkin Birbudak, Romanya'nın Bağımsızlı̆ın Kazanması, Gazi Üniversitesi Sosyal Bilimler Enstitüsü Yayınlanmamış Doktora Tezi, Ankara 2014, ss. 137-141.

4 Maxim, "Romanya", s. 170; Uğuz, a.g.t, s. 291.

5 İbrahim Edhem, Plevne Hâtrralar, Yay. Haz: Seyfullah Esin, Tercüman 1001 Temel Eser, İstanbul 1979, s. 77; Turhan Şahin, Öncesi ve Sonrasiyla 93 Harbi, Kültür Bakanlığ1 Yayınları, Ankara 1988, s. 121; Archibald Forbes, Czar and Sultan, New York 1894, s. 280, 294 
nehrin 30 adım kadar yakınlarında olmalarına rağmen Ruslar, askerlerin bu sudan içmesine dahi müsaade etmiyorlard1. ${ }^{6}$

Gazi Osman Paşa'nın, esaretini Harkov'da geçirmesi kararlaştırılmıştı. Ancak Osman Paşa ilk önce Bugot’taki karargâha, oradan 26 Aralık 1877 tarihinde Bükreş’e götürülmüştü. Paşa, Bükreş’te Grand Hotel'in ilk katında yer alan üç odalı dairede kalmıştı. Bükreş halkı, Plevne'de topraklarını kahramanca savunan bu kahramanı heyecan içerisinde beklemekteydi. Otele geldiği sırada küçük bir kız çocuğu, bir demet çiçeği Gazi Osman Paşa’ya takdim etmişti. Paşa da buna mukabil küçük kızı kucağına alarak ona sevgisini göstermişti. ${ }^{7}$ Buradan ayrılan Paşa, daha sonra Harkov'a götürülmüştü. ${ }^{8}$

Plevne'nin Rusların eline geçmesinden sonra Osman Paşa komutasındaki birlikten yaklaşık 2.500 subay, 43.430 er Ruslara esir düşmüştü. Bunlardan 4.000’i ağır yaralı ve hasta oldukları için Plevne'de bırakılmıştı. ${ }^{9} \mathrm{Bu}$ kadar büyük miktardaki esirin nakli Rusya açısından ciddi bir sorundu. Çünkü Ruslar denetimleri altındaki birkaç demir yolu hattını başka amaçlarla kullanmaktaydılar. Bu sebeple esirleri demir yolu ile sevk etmeleri mümkün olmadı. Kışın şiddetini artırdığı bir tarihte esir kafilesine refakat edecek askeri temin etmek ve bunları da benzer şartlarda sevkiyata memur etmek sorunlara sebep olabilirdi. İşte belki bu sıkıntıları öngören Ruslar, esirlerin bir kısmını Romanya'nın sorumluluğuna bırakarak mesuliyeti paylaşılmış oldular. Ruslar, esirler için sarf edecekleri tutarın yarısını karşılamayı taahhüt ederek, esirlerin bir kısmını alması hususunda Rumenleri ikna etmişlerdi. ${ }^{10}$ Aç ve kıyafetleri düzgün olmayan bu esirlerin 10.000 kadarı ağır kış koşulları altında, karla kaplı yollarda Romanya’ya, geri kalanı ise Rusya'ya götürülmüştü. Görgü tanıklarının büyük bir kısmı, esirlerin bu koşullarda hayatta kalmalarını imkânsız görüyorlardı. Zaten öyle de olmuştu. Plevne ile Bükreş arasındaki 200 kilometrelik mesafeyi ağır kış şartları altında kat eden esirlerin ciddi bir kısmı soğuk hava ve salgın hastalık gibi nedenlerden dolayı Bükreş'e ulaşamadan hayatlarını

6 Manastırlı Mehmet Rıfat Bey, 93 Harbi Faciası, Haz: Tahsin Yıldıım, Dün Bugün Yarın Yayınları, İstanbul 2010, ss. 73-75; Enver Behnan Şapolyo, Türk-Rus Savaşlan Tarihi Gazi Osman Paşa ve Plevne Müdafaast, Türkiye Yayınevi, İstanbul 1959, s. 199.

$7 \quad$ Vakit Gazetesi, Numara: 791, 5 Ocak 1878.

8 Uğuz, a.g.t., s. 284; M. Metin Hülagü, Gazi Osman Paşa Yarah Maresal, İzmir 2006, ss. 199-200.

9 BOA, HR. TO, 521-30; Basiret Gazetesinin haberine göre Plevne'de esir tutulan Osmanlı askerinin sayısı 40.000 'di. Hasta ve yaralıların miktarı ise 20.000 civarında olduğu tahmin edilmekteydi. Basiret, 11 Aralık 1878; Uğuz, a.g.t., s. 137.

10 Basiret, 21 Aralık 1878; Uğuz, a.g.t., s. 137. 
kaybetmişlerdi. Plevne'den sevk edilen esirlerin tahminen 4.000'den fazlası yolda donarak veya açlıktan yaşamını yitirmişti. ${ }^{11}$ Esir kafilesinin durumunu yakından müşahede etmiş bir görgü tanı̆̆ı, esirlerin sevkiyatını şu şekilde tasvir etmekteydi:

"Karla kaplı düzlüklerde sadece siyah telgraf direkleri ve leş yiyici kargaların güçlü kanat çırpma sesi vardı. Kısa bir süre sonra leş yiyici kuşların sayıları o kadar arttı ki kurşunî gökyüzü neredeyse simsiyah olmuştu. Sonra uzaktan, ufku kıran, uzun koyu bir çizgi, yol boyunca tırtıl görüntüsünde bize doğru geliyordu. Bu bir erkek konvoyuydu. Rus askerleri ya da Rumenler kar üzerinde yankılanan neşeli bir şarkı duymuyorlardı. Bu Türk mahkûmların konvoyu olmalıydı. Çünkü çeşitli malzemelerinin ağırlığı altında isteksiz bir şekilde yavaş yavaş ilerlerlerken Rumen ordusu muhafizlarının süngüleri önlerinde sallanıyordu. Türk subaylarının bazıları küçük atlara binmiş, bazıları yaya olarak ilerlemekteydi. Onların arkasında Plevne civarında görev yapmış Rus askerleri, serseri bir şekilde ilerliyordu. Ne kadar ruhsuz ve zoraki bir yürüyüştü. Yarı aç, yorgunluk ve soğuğun şiddetinden neredeyse ölmüş olan bu askerlerin çoğunun gözlerinden ateş çıkıyordu. Osman Paşa'ya şöhret kazandıran cesur birlikleri geliyordu. Onları sinsice sadece kemikler ve elbise paçavraları takip ediyordu. Tifüs ve çiçek hastalığı dondurucu havada zavallı esir konvoyunun etrafinda dolaşırken, zavallı yaratıkların rüzgârına iyice yaklaşıyorduk. Hatta bazıları bu esnada kafileden ayrılarak yere düşüp ölüyordu. Sefil bir esir, kendini yol kenarında karın üzerine attı, artık daha ileri gidemezdi. Ondan ayrılmak istemeyen bir arkadaşı bitkin düşmüş askerin peşine giderek onu konvoya katılmaya ikna etmek için çabaladı. Ancak hiçbir karşılık alamadı. Esir asker bayılmış ya da ölmüştü. Kafilenin arkasından ilerleyen muhafizlardan biri karın içerisine yuvarlanan askerlerin yanına gelerek, kaba bir şekilde hayatta olan esiri kafilenin içine itti, sonra ayağıyla karın yüzeyinde uzanan diğer askeri itekledi, ancak her hangi bir ses yoktu. Silahının dipçiği ile esir askerin karın içinde kalan kafasını çevirdi, ancak esirin gözleri ona soğuk ve donuk bir şekilde bakmaktaydı. Türk ölmüştü. Öldüğünü düşündüğü bu esiri, vahşice karın içine doğru itekledi, tüfeğini omuzuna attı ve tekrar muhafız birliğine katıldı.

Osmanlı Devleti ile Romanya temsilcileri arasında 24 Aralık 1879 tarihinde yapılan toplantı tutanağının tercümesi ve Romanya Siyasiye Nezareti tarafından tanzim edilmiş olup 1 Ekim-11 Aralık 1878 tarihleri arasında Osmanlı esirleri için sarf edilen meblağı gösterir tablonun tercümesi, BOA, HR. TO, 521-30; Edmund Ollier, Cassell's Illustrated of the Russo-Turkish War, c. II, London 1890, ss. 3-4; Birbudak, a.g.t., s. 147-148; Şahin, a.g.e., ss. 122-123. 


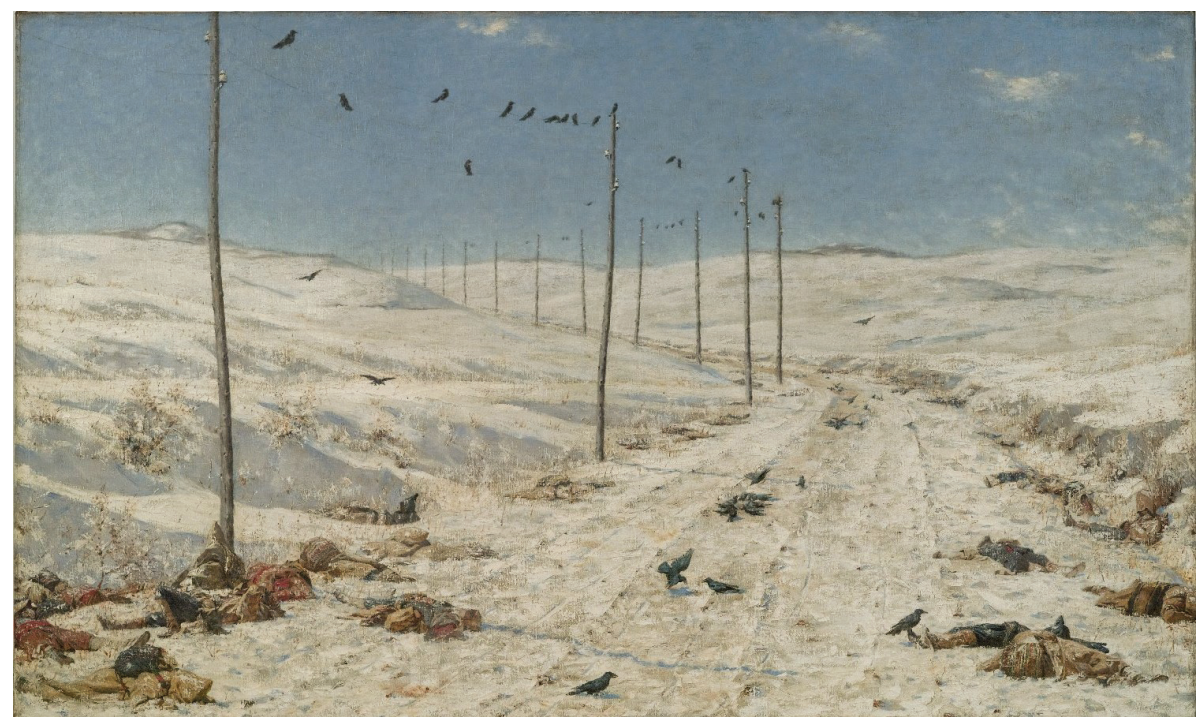

Resim 1: Vasily Vereshchagin (Rus, 1842-1904)'in esir konvoyunun bu yürüyüşünden esinlenerek çizdiği The Road of the War Prisoners (Savaş Esirlerinin Yolu) (1878-1879) isimli tablosu.

Binlerce yırtıcı kuş kafilenin önüne ve arkasına üşüşerek sefil kafileyi acımasız bir şekilde tıpkı batmakta olan bir geminin etrafındaki köpekbalıkları gibi takip etmekteydi. Birkaç metre ileride, yarısı karla kaplı ve üzerindeki eskimiş elbiseleri, biraz daha sıcak kalabilme gayesiyle arkadaşları tarafindan alınmış, başka bir Türk’ün çılak bedeni uzanıyordu. Leşçil bir karga ölmüş bir esirin eline henüz konmuştu ve köpekler kurbanlarının etrafinda dönüyorlardı. Birkaç adım ötede hızla yağan kar nedeniyle yüzü gökyüzüne sabit bir şekilde bakan ve hayata gözlerini yummuş diğer bir sefil esiri bize getirdiler. Şimdi bir köyün yanındayız, bir köpek ile domuz arasındaki soğuk cesede ilk hangisinin ulaşacağına karar vermek için yapılan dalaşmaya şahit olduk. Burası Putinein köyüydü ve köy neredeyse kar ve buzun içinde kaybolacaktı. Bu köy, Tuna'nın en iyi geçiş noktası olarak bilinen Dragomiroff'u ararken, ilk kez yaz başında geçtiğim zamanki görüntüsünden ne kadar farklı görünüyordu. O zamanlar sivrisineklerden, bunaltıcı sıcaktan ve kör edici tozdan muztariptik, şimdi ise soğuktan dolayı kürklerimizin içinde titriyoruz." 12

12 Forbes, a.g.e., ss. 294-295. 


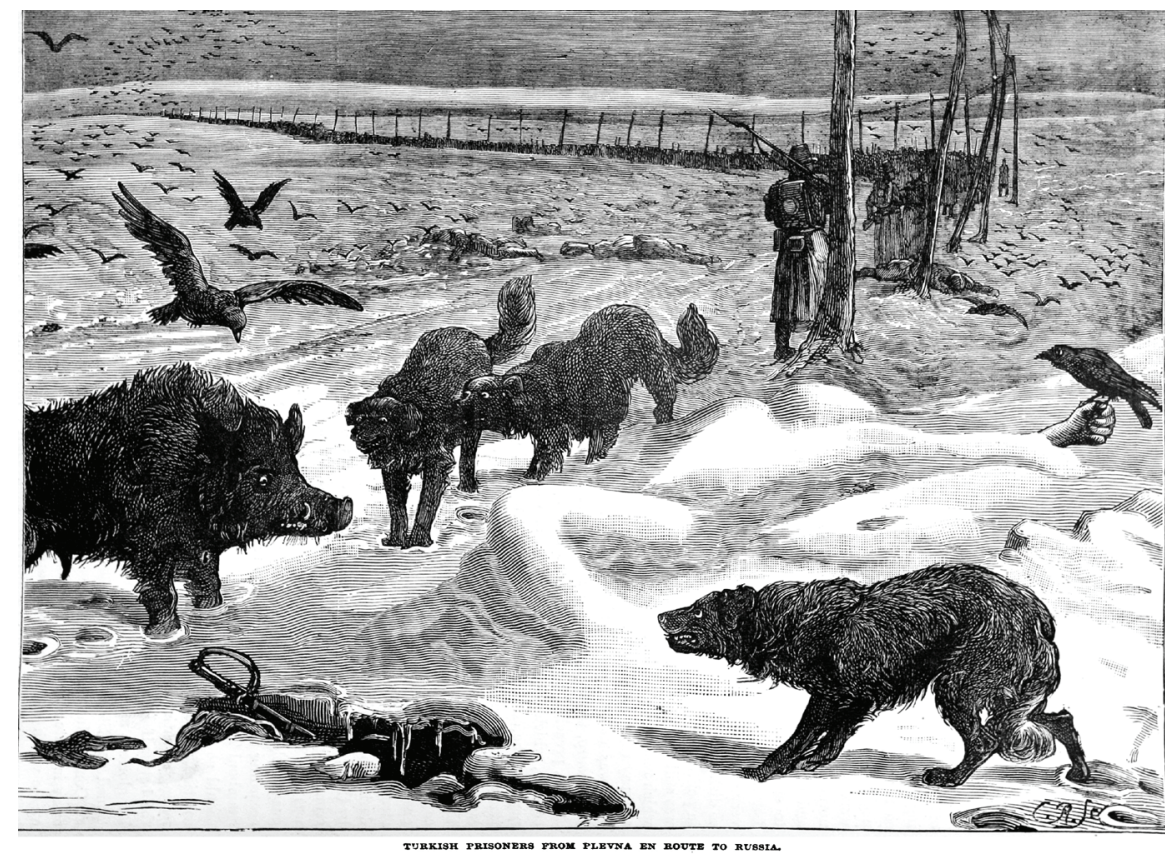

Resim 2: Plevne'den Rusya'ya Giden Türk Esirleri

Bu köyde ölüm evine sığınıp tedavi edilen Türk esirlerin bazıları yanlarında ölen arkadaşlarının cesetleri arasında boşluk oluşturarak soğuktan korunaklı bir yer meydana getirmek için uğraş verdiler. Kulübede, ölen arkadaşlarının elbiselerini alıp cılız bir ateş yakarak soğuktan korunmaya çalıştılar. Bu hengâmede gece boyunca birazcık ısınmak için mücadele ettiler. ${ }^{13}$

Esirlerle karşılaşıp yaşananlara tanıklık etmiş Peşteli iki tüccarın Osmanlı muayene memurlarına anlattıkları, Türk esirlere yapılanların vahametini ortaya koymaktaydı. Buna göre Plevne'de esir edilip Niğbolu'ya gelinceye kadar soğuktan ve hastalıktan hayatını kaybeden askerlerden 3.500 kadarı defnedilemeyerek yollarda kalmıştı. Ulahlılar, bu cenazelerin üzerlerinden arabalar ile gelip geçmekteydi. Ulahlıların, Osmanlı esirlerine uyguladıkları vahşet ve barbarlık şimdiye değin hiçbir milletin izin vereceği bir şey değildi. Yaşananlar insan kalbinin tahammül edemeyeceği derecedeydi. Esirlerden hasta ve paralı olup da yürümeğe gücü yetmeyenleri nakletmekle sorumlu olan memurlar bu esirleri yürek dayanmayacak 
şekilde darp edilmekteydi. Büsbütün takati kalmayıp yere düşenler bellerinde bulunan kuşaklar ile boğazlarından arabaların arkalarına bağlanıp çekiştiriliyordu. Arabalar hareket ettikçe bu biçareler yerlerde sürüklene sürüklene boğulup yaşamını kaybediyordu. Şehirlerde hayatını kaybedenler ise halkın gözünde bırakılmayarak polis tarafindan birer çift öküzün arkasına bağlanarak defnedilecekleri yere kadar sürüklenip atılmaktaydılar. Bu askerlerin çoğu soğuktan, bir haylisi açlıktan hayatını kaybetmekteydi. Bunlar sokakta ötede beride bırakılıp bakılmadığından bu iki tacir bir kaçını kendi mağazalarına alıp tedavi etmiş, daha sonra da hastaneye götürüp teslim etmişlerdi. Bu esirlerin perişan hallerini görüp yardım etmek isteyen kişilere de Ulahlar ve Bulgarlar engel olmaktaydı. Bundan başka askerlere verilen tütün, ekmek ve saire gibi şeyler askerin elinde görüldüğünde alınmaktaydı. Askerlerin ve subayların üzerlerinden bulunan para ve sair eşya gasp edilmişti. ${ }^{14}$

Plevne'yi uzun süredir kahramanca savunan bir orduya karşı yapılan bu utanç verici muamele oldukça kötü bir tablo arz etmekteydi. Avrupa basını esirlerin ölüm yürüyüşünü sayfalarına taşıyınca aleyhine bir hava oluşan Rusya, karşı propagandaya başlamıştı. Rus gazeteleri, Gazi Osman Paşa'nın, Plevne'yi savunurken emrindeki askerlere, ellerinde tuttukları 150 kadar Rus esirini diri diri toprağa gömme emri verdiğini iddia etmekteydi. ${ }^{15}$ Yine savunma sırasında meydana gelen savaşta Rus askerinden yaralı olanlar ile kollarında Kızılhaç kolluğu olan sedyecilerin Osmanlı askeri tarafindan eziyetle öldürüldükleri propagandası yapılıyordu. ${ }^{16}$ $\mathrm{Bu}$ sayede Türk esirlerine yapılan kötü muamele meşruiyet kazanmıs, Tuna'da Müslümanlara karşı yaptıkları gaddarlıkların Avrupa kamuoyunda oluşturduğu olumsuz tesir ortadan kaldırılmış olacaktı. Ancak Gazi Osman Paşa, haberi yapan gazetelere, bu bilginin bir iftiradan ibaret olduğunu, böyle bir vahşi muameleye ilk karşı çıkacak kişinin kendisi olacağını ifade eder bir mektup göndermişti. ${ }^{17}$ Tam aksine Ruslar, Ardahan vakasında ve daha sonra Rusçuk ve Sohum'da üzerlerine Kızılay bayrağı çekilmiş hastaneleri topa tutarak bu hastanelerin içinde bulunan yaralı askerlerinin çoğunu şehit etmişlerdi. ${ }^{18}$ Ayrıca savaş sırasında Rus ordusu içerisinde bulunan Alman subaylardan birinin Berlin'e göndermiş olduğu ve "Rus ordusunun eline düssen yaralı Türk askerlerinin ceplerindeki paralarına bakıldı"

14 Adakalesi Muayene Memuru Ali ile Asım’n 13 Muharrem 1295 (17 Ocak 1878) tarihli arizası, BOA, HR. SYS, 1-4.

15 Basiret, 20 Şubat 1878; Uğuz, a.g.t., s. 310.

1624 Ağustos 1877 tarihli sadaret tezkiresi, BOA, Y. EE, 84-100.

17 Basiret, 20 Şubat 1878; Uğuz, a.g.t., s. 310.

1824 Ağustos 1877 tarihli sadaret tezkiresi, BOA, Y. EE, 84-100.

Belleten, Ağustos 2020, Gilt: 84/Sayı: 300; 789-824 
cümlesini ihtiva eden mektup ve savaş alanında bulunan bazı Avrupalı gazetecilerin müşahedeleri, Alman İmparatoruna kadar ulaşmıştı. Alman İmparatoru konu ile ilgili üzüntüsünü İstanbul'da bulunan elçisi aracılığıyla Hariciye Nezaretine ileterek bahsi geçen yazıları Hariciye Nazırına teslim ettirmişti. ${ }^{19}$ Oysa "hasta ve yarah askerler hangi millete mensup olursa olsunlar toplanacak ve tedavi edileceklerdir" şartını ihtiva eden Cenevre Sözleşmesi'ne, 1865 yılında Osmanlı Devleti, 1867 yılında da Rusya imza koymuştu. ${ }^{20}$

\section{Bükreş'teki Esir Türk Askerlerinin Durumu}

Esirler, 23 Aralık 1877 tarihinde Bükreş'e varmaya başlamışlardı. ${ }^{21}$ Şehre ulaşan esirler iyi muamele ve saygı gördüler. Romanya Prensi Carol dahi hastanelere yerleştirilen yaralıların bizzat yanına giderek tek tek hatırlarını sordu. Yetkililere, Osmanlı askerlerine bir esir gibi değil de misafir gibi davranılması ve onların bakımlarına ihtimam gösterilmesi hususunda emirler verdi. ${ }^{22}$ Ağıı kış şartlarında esirleri Bükreş'e götürenler, esirlere gece dinlenme esnasında üşümemeleri için olabildiğince birbirlerine yakın bir şekilde oturup dinlenmelerini telkin etmişlerdi. Buna rağmen birçok esir soğuk ve açlığın etkisiyle yaşamını yitirmişti. Kalanlar da açlık, soğuk ısırması, dizanteri, tifüs ve ishalden dolayı çok acı çekmekteydi.

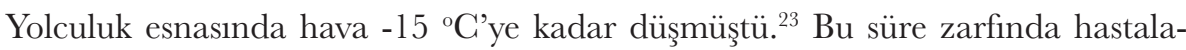
narak ve sair sebeplerden dolayı yaşamını yitiren 33 asker, Dealu Manastırı'na defnedilmişti. Bu askerlerin defnedildiği yere onları sembolize eder herhangi bir nişan konulmamıştı. ${ }^{24}$

Rusya’ya götürülen esirler bu kadar şanslı değildi. Onların daha kat edecekleri epeyce bir yolları vardı. Bu süre zarfinda soğuk havanın tesirinden korunmak için sürekli birbirlerine sokularak hareket eden esirlerin başındaki Rus askerleri merhametli olmadığı gibi, esirlere verdikleri tayinatın hiçbir düzeni yoktu. Ruslar, 
esirlerin arasına sanki hayvana yem veriyormuş gibi somun parçaları atıyorlardı. Esirler günlerdir aç, susuz, yorgun ve uykusuz bir halde bu ekmekleri kapmak için birbirleriyle mücadeleye girişiyorlard1. ${ }^{25}$

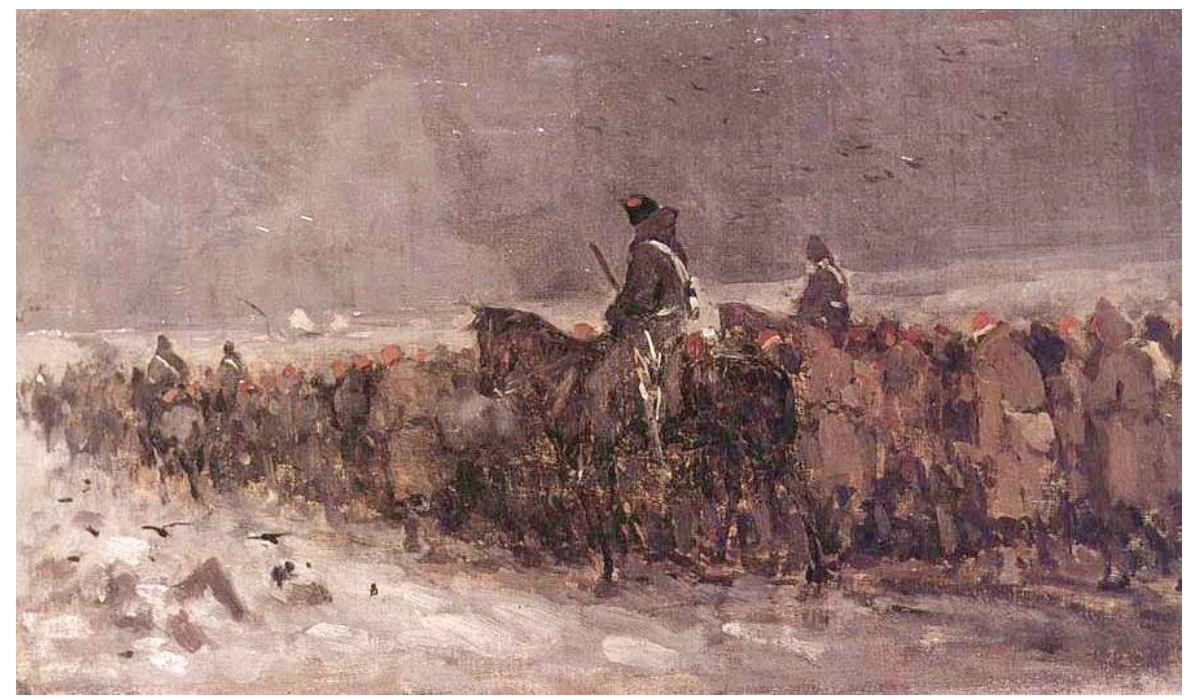

Resim 3: Nicolae Grigorescu'nun Convoi de Prizonieri Turci (Türk Esirler Konvoyu) isimli tablosu.

Yaklaşı 5 ay muharebe eden bu esirler bitkin ve sefil bir haldeydiler. ${ }^{26}$ Ancak bütün bu olumsuzluklara rağmen Bükreş'te bulundukları sırada yabancılarla irtibatlarında neşeli, iyi huylu ve vakur bir tavır sergilemişlerdi. ${ }^{27}$ Rus üniformasının görülmeye alışldığı Bükreş’te artık her yerde Türk fesi beliriyordu. Rumenler gelen Türk esirlere neredeyse kendi askerleriyle ilgilendikleri derecede alaka gösteriyorlardı. Öyle ki Romanya Savaş Bakanlığı, Bükreş’te bulunan küçük bir İngiliz hastanesinin boş yataklarına yaralı Rumen askerleri yerine Türk hastaları doldurması yönünde emir vermişti. Bakanlığın bu emrine İngiliz hastanesi çalışanları dahi şaşırmıştı. Bu hastane 21 yaralı Türk'ü kabul edebilmişti.

Esirlerden bir kısmının soğuktan el ya da ayakları kangren olmuştu. Bunlar tedavi gördükten sonra ancak koltuk değnekleri ile yürüyebileceklerdi. Tedavi sırasın-

25 Ollier, a.g.e., ss. 3-4.

26 BOA, HR. TO, 521-30.

27 StuartJ. Reid, Memoirs of Sir Wemyss Reid 1842-1885, Outlook Verlag, Frankfurt 2018, s. 160. 
da subayların bir kısmı derin bir tevekkülle yataklarında yanlarında getirdikleri Kur'an-ı Kerim'leri okuyorlardı. Askerler arasında en yaygın görülen hastalık tifüstü. Bu hastalık sağlık personelini de tehdit eder bir boyutta hüküm sürmekteydi. Bu yüzden esirlerle ilgilenen sağlık personeli ihtiyatlı davranıyordu. Çünkü esirlerle ilgilenen iki ya da üç Rumen doktor ile birkaç hemşire hayatını kaybetmişti. Artık Bükreş’teki hastaneler daha fazla hasta alamaz hale gelmişti. Bundan sonra hasta ve yaralıların bir kısmı civardaki hastaneye dönüştürülen bazı manastırlara gönderildi. Bu süre zarfinda hastanelerin doluluğundan dolayı hastane hastane dolaştırılan yaralı esirlerin bir kısmı yaşamını yitirmişti. Tifüsten ölen bazı esir askerlerin naaşları hastalık yaymaması için yakılmıştı. ${ }^{28}$

Askerler esir düşüp sefil bir hayat yaşamanın öfkesiyle, 93 Harbi’nin büyük paşaların ihtirası yüzünden çıktığını ifade etmekteydiler. Bir suçlu lazımdı, onlara göre özellikle Midhat Paşa ve Müşir Mehmed Ali Paşa bu suçlular arasındaydı. Esir askerler, Rusların iyi niyetli olduğunu ve savaşmak istemediklerini, onları savaşa kendi komutanlarının teşvik ettiği yönünde kanaat besliyorlardı. Paşaların uyuşmaz tavrı nedeniyle savaş yaşanmış ve Türk askeri perişan olmuştu. Çünkü paşalar savaşı kazanacaklarını ve savaştan sonra ün salmış zengin kişiler olacaklarını düşünmekteydiler. Her zaman olduğu gibi başarıya sahip çıkan çok oluyor ama başarısızlığa suçlu aranıyordu. Önce Ruslara esir düşen bu kişiler, yukarıdaki ifadelerin aleyhine, Rusların kendilerine nazik davrandığını ve yiyecek verdiğini ifade ettikten sonra Romanya'ya getirildiklerini söylemişlerdi. ${ }^{29}$

Bir grup esirin yanına gelen İngiliz bir doktor ve hemşire, donan askerleri uzaklaştırarak zor durumda olan diğer askerlerle ilgilenmişti. Onlara ekmek, bal, ispirtolu eriyik, sigara ve sair şeyler getirmişler ve esirlerden bazılarını sıcak odalara yerleştirerek onlara yakmaları için kibrit ve saman bırakmışlardı. ${ }^{30}$

Türk esirler, Bükreş’te kaldıkları müddetçe belli bir miktar yemek ve birtakım ihtiyaçlarını karşılamaları için beş para tayinat almaktaydılar. Ancak kimi zaman verilen ekmekler küflü oluyordu. Bu askerlerin büyük bir kısmı yaralıydı. Bazısının

The Lancet, March 23, 1878, s. 439.

Osmanlı Devleti ile Romanya temsilcileri arasında 24 Aralık 1879 tarihinde yapılan toplantı tutanağının tercümesi ve Romanya Siyasiye Nezareti tarafından tanzim edilmiş olup 1 Ekim-11 Aralık 1878 tarihleri arasında Osmanlı esirleri için sarf edilen meblağı gösterir tablonun tercümesi, BOA, HR. TO, 521-30; Henry C. Barkley, A Ride Through Asia Minor and Armenia, London 1891, s. 5 .

Barkley, a.g.e., ss. 6-7. 
yarası yüzeysel, bazısınınki ise derindi. Yaralarından dolayı hayatını kaybedenler de bulunmaktaydı. Esirler Bükreş'te nereye isterlerse gidebilmekte, serbestçe dolaşabilmekteydiler. Günlerinin çok büyük bir kısmını bu şehrin bahçelerindeki ağaçların altında geçirmekteydiler. Başlangiçta Lipscani ve Tchesmagu Bahçelerinde sefil bir hayat süren esirler, belirsiz akıbetlerinden endişe ediyorlardı. İmkân bulan Türk esirler, Bükreş'e gelen Bulgar tüccarlardan medet ummuşlar ve Bulgar tüccarlar da onlara şapka ve Fransız giysileri vererek esirleri uşakları sıfatıyla Osmanlı topraklarına götürmüşlerdi. Ancak Bulgarların çok büyük bir kısmı Türk esirlerine oldukça kötü davranmaktaydı. Kalan Türk esirler, buna rağmen gördükleri her tüccardan kendilerini İstanbul'a götürmesi için ricada bulunmaktaydı. ${ }^{31}$

Bükreş'te gözetim altında tutulan Türk esirlerini görenler, onları genellikle yenilmiş ama cesur ve sabırlı olarak tasvir etmekteydi. Kimseden para dilenmeyen esirler, kendilerini kadere teslim etmiş bir görüntü sergilemekteydiler. ${ }^{32}$ Bir kısmı ise kendilerine tahsis edilen gündeliğin az olmasından dolayı bunu artırmak için her türlü işte çalışmaya hevesli gözükmekteydiler. ${ }^{33}$ Görgü tanıklarına göre onlar, şan ve şerefle evlerine çağrılmayı bekleyen kahramanlardı. Esirlerin Romanya'da bulundukları süre zarfinda edibâne tavır ve hareketleri hükümet ve ahali ile olan münasebetleri takdir görmüş ve bu husus, savaştan sonra Osmanlı Devleti'nin Bükreş sefiri olarak atanan Süleyman Sabit'e defaten beyan edilmişti. ${ }^{34}$ Aslında Rumenler daha Plevne'nin ilk düştüğü anda Türk askerine sevgi gösterilerinde bulunmuşlardı. Rumenler burada 23 yıl önceki Kırım Savaşı’nda, kendilerini Rusların baskısından kurtaran Türk askerini saygı ile karşılamışlardı. ${ }^{35}$ Rumenlerin Türk askerine olumlu bakış açısı Romanya'nın ünlü ressamı Nicolae Grigorescu'nun (d. 1838- ö. 1907) tablolarına da yansımıştı. Özellikle Prizonieri Turci (Türk Esirler) isimli tablosunda esirlerin kendinden emin, mağrur vaziyeti dikkati çekmektedir. ${ }^{36}$

31 Barkley, a.g.e., ss. 4-10.

32 Bükreş Sefiri Süleyman Sabit tarafindan Hariciye Nezaretine gönderilen 18 Kânun-ı Evvel 1294 (30 Aralık 1878) tarihli tahrirat, BOA, I. HR, 335-21539.

33 Reid, a.g.e., s. 160.

34 Bükreş Sefiri Süleyman Sabit tarafindan Hariciye Nezaretine gönderilen 18 Kânun-ı Evvel 1294 (30 Aralık 1878) tarihli tahrirat, BOA, I. HR, 335-21539.

35 Şahin, a.g.e., s. 124.

36 Bakınız Resim 4, Nicolae Grigorescu'nun Turkish Prisoners isimli tablosu Romanya'nın Cluj-Napoca şehrinde bulunan Museum of Art isimli mekânda sergilenmektedir. 


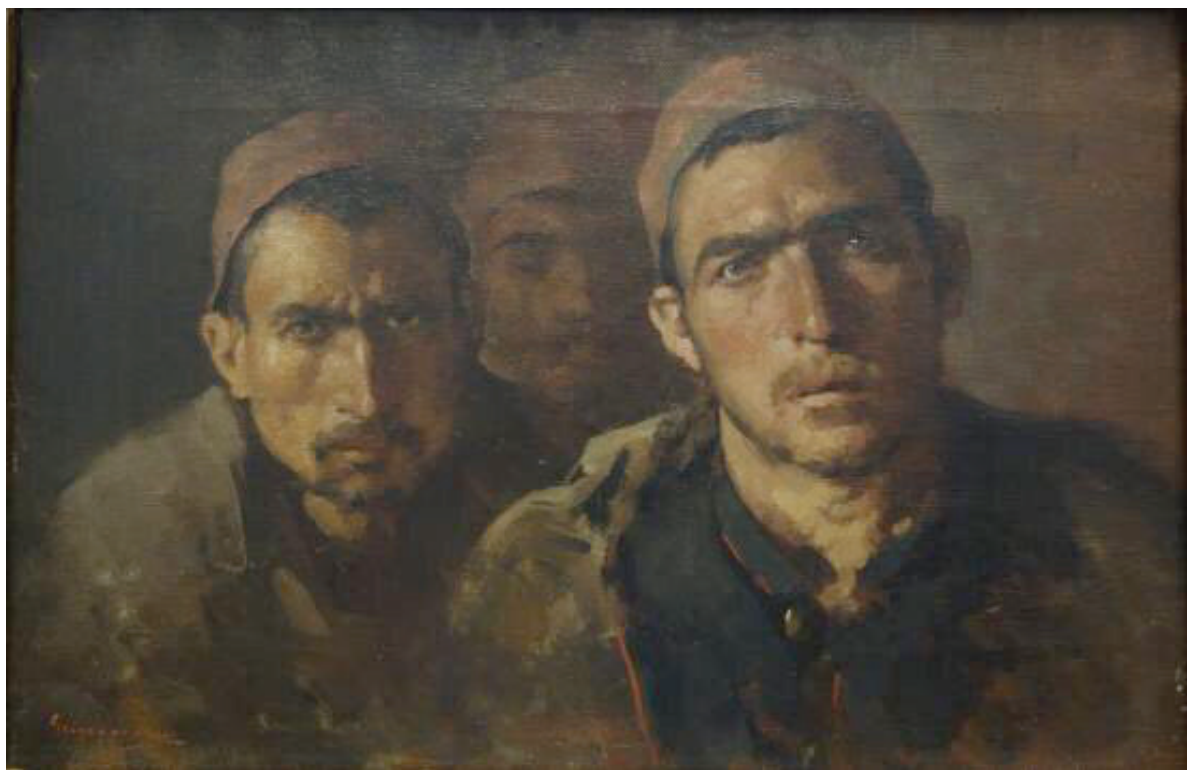

Resim 4: Nicolae Grigorescu'nun Prizonieri Turci (Türk Esirler) isimli tablosu

Bu sırada Romanya hükümetinin Ruslara karşı olan bakış açısı değişmeye başlamışı. Aslında Rumenlerin, Ruslarla ittifakı mecburiyetten kaynaklanmaktaydı. Bâbıâli'nin 1876 ylında yayınladığı meşrutiyet beyannamesinde Romanya'nın Osmanlı Devleti'ne tâbi muhtar bir eyalet olduğu yönündeki hüküm, kendilerini bağımsız hisseden Rumenleri, Rusya'ya mecbur bırakmıştı. Ayrıca Rumenler savaş sırasında tarafsız kalmak için çabalamışlar, fakat Osmanlı Devleti'ne ve Avrupalı devletlere yaptıkları müracaattan bir sonuç alamamışlardı. Rumenler çıkabilecek Osmanlı-Rus savaşının başından sonuna kadar Osmanlı Devleti lehine tarafsız kalacaklarını, gerekirse tarafsızlıklarını korumak için Ruslarla savaşı göze alacaklarını özel temsilcileri vasıtasıyla Bâbıâli'ye bildirmişlerdi. Bunun karşılığında Osmanlı Devleti’nden kendilerinin bağımsızlı̆ıını tanımalarını talep etmişlerdi. Buna karşın Osmanlı Devleti yetkilileri stratejik bir hata yaparak kendi hâkimiyetinde olan Romanya'nın tarafsız kalamayacağını, ancak kendisiyle ittifak ederek savaşa girmeleri gerektiğini ifade etmişlerdi. ${ }^{37}$ Avrupalı devletler de Romanya'nın tarafsızlı̆̆ını garanti etmekte çekimser kalmışlardı. Rumenler bahsi geçen sebep-

37 Yuluğ Tekin Kurat, "1877-78 Osmanlı-Rus Harbinin Sebepleri”, Belleten, XXVI/103, Temmuz 1962, s. 592. 
lerden ve Osmanlı Devleti ile olan bağlarını sonlandırmak istemelerinden dolayı, çok istekli olmasalar da Ruslarla işbirliği içerisine girmişlerdi. Rumenler, savaş s1rasında bağımsızlıklarını tanıyan Rusların savaş bittikten sonra kendi toprakları üzerinde nüfuz mücadelesine gireceklerinden endişe ediyorlardı. 1856 Paris Antlaşması ile Besarabya’yı Romanya'ya kaptıran Rusya'nın bu bölgeyi almak emelinde bulunduğunun farkındaydılar. ${ }^{38}$ Ruslara göre, bu savaş sırasında Napolyon, seksen milyon Rusya ahalisinin tarihi mirasina hakaret olarak Besarabya'yı Rusya'dan alıp Memleketeyn (Romanya)'e vermiş idi. ${ }^{39}$ Bu sebeple daha savaş bitmeden Bükreş’e gelerek Rumen ordusu ile birleşip Tuna Nehri’ne doğru ilerleyen Rus ordusunu pek sevecen karşılamamışlardı. ${ }^{40}$

3 Mart 1878'de 93 Harbi’ni sonlandıran Ayastefanos Antlaşması'nın imzalanmasıyla bağımsızlığı tasdik edilen Romanya, savaştan önce kendi toprağı olan Besarabya’yı, Dobruca karşılığında Rusya'ya kaptırmıştı. Bu durum Romanya'nın hoşnutsuzluğunu artırdığı gibi Rusya'ya karşı denge unsuru olabilecek devletlere yanaşmasına neden oldu. Romanya için denge unsuru olabilecek devletlerden biri de Osmanlı Devleti idi. Antlaşmanın imzalanmasından birkaç gün sonra, Osmanlı Devleti'nin Viyana'daki sefiri ile irtibata geçen Romanya hükümeti, kendilerinin Bâbıâli ile ayrı bir barış antlaşması imzalamaya hazır olduğunu, bunun yanında Ayastefanos Antlaşması'nda Romanya adına Rusya tarafindan eklenen maddelerin hiçbirini tanımadıklarını ifade ediyorlardı. Besarabya karşılığında Romanya hükümetine ne vaat edilir ise edilsin bunun Romanya hükümeti tarafindan kabul edilmeyeceğini bildirdiler. Bağımsızlığın tanınması hususunda Rusya’ya minnet duymaktansa bu minneti Osmanlı Devleti'ne duymayı yeğliyorlardı. Zaten Bâbıâli açısından Romanya'nın bağımsızlı̆̆ını onaylamak kaçınılmaz bir durumdu. Anlaşılacă̆ı üzere Romanya’nın anlaşmak için Bâbıâli’ye karşı öne sürdüğü tek husus bağımsızlığının tanınmasıydı. ${ }^{41}$ İlerleyen tarihlerde de esirlerin değişimi için Romanya Ayan Meclisi Başkanını İstanbul'a gönderen Romanya hükümeti, bu hususta bir mukavele imzalama talebinde bulunmuştu. Ancak Bâbrâli açısından

38 Kurat, a.g.m., s. 592.

39 Vakit, Numara 835, 18 Şubat 1878/14 Safer 1295.

40 Mahmud Celâleddin Paşa, Mir'at-ı Hakîkat II, (Haz: İ. Miroğlu, M. Derin, M. Halacoğlu, Ö. Akdaş), Tercüman 1001 Temel Eser, İstanbul 1980, ss. 131-133; Midhat Sertoğlu, Mufassal Osmanl Tarihi, c. VI, Türk Tarih Kurumu Yayınları, Ankara 2011, ss. 3303-3304.

41 Osmanlı Devleti'nin Viyana Sefaretinden Hariciye Nezaretine çekilen 11 Mart 1878 tarihli telgraf, BOA, Y. PRK. HR, 2-53; Ayrıca bakınız Layard'dan Salisbury'ye gönderilen 3 Haziran 1878 tarihli belge, Kemal H. Karpat, Balkanlar'da Osmanl Mirası ve Ulusçuluk, Çev: Recep Boztemur, İmge Kitabevi, Ankara 2004, ss. 368, 369. 
hâlâ Memleketeyn olan Romanya hükümeti ile bir mukavele imzalamak buranın bağımsızlığını zımnen tanımak anlamına gelecekti. Bu yüzden bu temaslar da sonuçsuz kalmıştı. ${ }^{42}$

Rusların Besarabya'yı Rumenlerden almasından dolayı Rumenler, Ruslara açıktan açığa husumet besliyorlardı. Rus ve Rumen memurlar sokak veya kafelerde karşılaştıklarında birbirlerine düşmanca bakmaktan çekinmiyorlardı. Rumenlerin, Ruslara olan bu düşmanca tutumu sadece Besarabya meselesinden kaynaklanmıyordu. Onlara göre Ruslar, Plevne kuşatması sırasında Rumen askerlerini bencilce feda etmişlerdi. ${ }^{43}$ Rus askerlerinin Romanya'yı terk etmeye başladığı tarihlerde Romanya'nın Romanol gazetesi, Ruslara atfen "inşallah giderler de bir daha Prut'u geçmeye muvaffak olamazlar" diye yazmaktayd. ${ }^{44}$ Rumenlerin Türk esirlere merhametli tavrı, Türkler üzerinde Romanya'ya karşı çok olumlu bir etki bırakmıştır. Rumenler, Türk esirlerin ülkelerine dönmeleri taraftarlarıydı, oysa Ruslar, Osmanlı esirlerinin ülkelerine dönüşleri önünde her türlü engeli çıkarmaktaydılar. $^{45}$

Hem mevcut siyasî durum, hem de esirlerin bıraktığı iyi intiba nedeniyle Romanya Prensi I. Carol, Plevne'de esir düşüp Bükreş'e getirilmiş olan Sadık ve Edhem Paşaları 12 Mart 1878'de huzuruna kabul edip, onların Osmanlı topraklarına dönmelerinde özgür olduklarını söyleyerek kendilerine kılıçlarını iade etmişti. Romanya Prensi'nin bu hareketi iki ülke arasındaki iyi niyeti gösterme açısından ilk somut adımdı. Prens, onlara Romanya'da bulunan Osmanlı esirlerinin güzel hal ve hareketlerinden memnun kaldıklarını tekrar beyan etti. ${ }^{46}$ Buna mukabil Sultan Abdülhamid de Sadık ve Edhem Paşalara üçüncü rütbeden birer Osmanlı Mecidiye Nişanı verdi. ${ }^{47}$

\section{Salisbury'ye gönderilen 17 Haziran 1878 tarihli belge, Karpat, a.ge.e, ss. 371-372.}

43

44

45

46 Mart 1878 tarihli telorafin tercümesi, BOA, HR. TO, 374-126. Romanya Hariciye Müdürü tarafindan Osmanlı Devleti'nin Hariciye Nezaretine çekilen 14 Mart 1878 tarihli telgrafin tercümesi, BOA, Y. PRK. HR, 2-55; Vakit, Numara: 873, 28 Mart 1878/23 Rebiyülevvel 1295.

47

Belleten, Ağustos 2020, Cilt: 84/Say1: 300; 789-824 


\section{Esir Değişim Mukavelesi ve Esirlerin İadesi Süreci}

Bu sırada Bâbıâli, Romanya'nın elinde bulunan esirleri alabilmek için Romanya hükümetiyle irtibata geçmişti. İki hükümet arasında müzakereler 1878 ilkbaharında başlamıştı. Bâbıâli, Mayıs 1878'de Romanya hükümetiyle yapılacak müzakereleri yönetmesi için Mirliva Süleyman Paşa ve Hersek Vilayeti Politika eski Memuru Azaryan Efendi'yi Bükreş'e göndermişti. ${ }^{48}$ Bâbıâli, Süleyman Paşa'ya esirlerin masraflarını ödeyebilmesi için 1.500 Osmanlı altınını "tertibat-ı fevkalade" kaleminden havale etmişti. ${ }^{49}$ Ardından temsilcilerin şahsî masrafları için de 16 Mayıs'ta $100^{50}, 13$ Haziran'da da 100 lira olmak üzere 200 lira daha göndermişti. ${ }^{51}$

Temsilciler esirlerin durumunu görüşmek için Mayıs ayından itibaren Bükreş'te bulunuyorlardı. Buna rağmen Romanya'da hâlâ hayatta olan 6.000 civarındaki Türk esirlerin durumu, Bâbıâli'nin çekincesinden dolayı bir türlü gündeme alınamamıştı. Konu ancak 13 Temmuz 1878'de Berlin Antlaşması'nın imzalanmasından sonra iki ülkenin gündemine girmişti. Bâbıâli daha önce de ifade edildiği gibi Berlin Antlaşması'nın imzalanmasından önce Romanya ile bir antlaşmaya varılmasını, bu devleti tanıma olarak görmekteydi. Bu sebeple Berlin'deki görüşmelerin neticelenmesini beklemişti. Artık esirlerin durumu Sultan II. Abdülhamid'in talimatı sonrasında Temmuz 1878'de Romanya Prensi Carol ile yapılan müzakereler neticesinde netleşecekti. ${ }^{52}$

Romanya Prensi Carol, Karpat dağlarında bulunan Sinyaya yazlığına gitmeden önce Bâbiâli'nin özel temsilcileri olan Süleyman Paşa ve Azaryan Efendi onuruna ziyafet vermiştir. Üst düzey devlet yetkililerinin bulunduğu bu yemekte Prens, Bükreş'te bulunan Osmanlı esirlerinin orada bulundukları süre zarfinda olumsuz hiçbir harekette bulunmamış olmalarını takdir etmişti. Buna binaen Osmanlı topraklarına dönememiş olan Osmanlı esirlerinin, bir an önce memleketlerine sevk

48 Süleyman Paşa ve Azaryan Efendi, 25 Cemaziyülahır 1295 (26 Haziran 1878) tarihinde sadır edilen buyuruldu ile Romanya ile yapılacak mukaveleyi akd ve imzaya yetkili kılınmışlardır. $B O A$, A. DVN. NMH, 24-9.

496 Rebiyülahır 1295 (9 Nisan 1878) tarihli sadaret tezkiresi ve 7 Rebiyülahır 1295 (10 Nisan 1878) tarihli irade-i seniyye, $B O A, \dot{I}$. $D H, 766-62403$.

5013 Cemaziyülevvel 1295 (15 Mayıs 1878) tarihli sadaret tezkiresi ve 14 Cemaziyülevvel 1295 (16 Mayıs 1878) tarihli irade-i seniyye, BOA, I. DH, 768-62565.

5111 Cemaziyülahır 1295 (12 Haziran 1878) tarihli sadaret tezkiresi ve 12 Cemaziyülahır 1295 (13 Haziran 1878) tarihli irade-i seniyye, BOA, I. DH, 769-62663.

52 Saltanat-ı Seniyye ile Romanya Hükümeti arasında yapılan görüşmeler neticesinde hazırlanan mukavelename, BOA, I. HR, 277-16906. 
edilebilmeleri için esirler meselesinin kesin bir şekilde çözüme kavuşturulması gerektiğini ifade etmişti. Prens aslında burada esirler konusunu açarak ağzındaki baklayı da çıkarmıştı. Vidin Kalesi’nde bulunan eski silah ve güllelerini, yalnızca tarihî kıymet taşıdığı için Osmanlı esirlerinin Bükreş’te bulunduğu sırada sarf edilen meblağa karşı ülkesine verilmesini talep ediyordu. Prensin yemek sirasında her firsatta konuyu buraya getirmesi muhtemelen yeni kurulan devlete tarihî bir geçmiş oluşturma amacı taşımaktaydı. Ancak, Vidin'de bulunan bu kalelerin mahzenlerinde yer alan eski silahların bir kısmı Ruslar tarafindan götürülmüştü.

Romanya hükümeti her ne kadar bu esirlerin iaşesini temin ediyor olsa da Bükreş’te bulunan birçok Bulgar, esirlere kötü söz söyleyerek onları tahrik ve rencide ediyordu. Neticede burada bulunan Türk esirler ile Bulgarlar arasında bir husumet ortaya çıktı. Türk esirlerin artık sinirleri geriliyor ve bunun her an bir asayişsizlik şekline dönüşmesinden endişe ediliyordu. ${ }^{53} \mathrm{Bu}$ arada Osmanlı Devleti'nin Rusya ile esir değişimi antlaşmasını yapması ve Rusya'daki esirlerin yakında vapurlarla sevkine başlanacak olması Bükreş’teki esirleri kendi akıbetleri hususunda telaşlandırıyordu. ${ }^{54}$ Her ne kadar orada bulunan iki Osmanlı temsilcisi sık sık esirlerin bulunduğu yerleri ziyaret etse de durum yatışmıyordu. Plevne esirlerinin sabırları tükenmek üzereydi. Bu sebeple 1.200 kişiden oluştuklarını ifade eden bir grup esir, kendi aralarında anlaşarak İstanbul'daki yetkililere, zarurî ihtiyaçlarını bile karşılamaktan aciz olduklarını, bir an önce akıbetleri hakkında kendilerine yetkililer tarafindan bilgi verilmesini talep etmişlerdi. Ancak onların telgrafları sansürlenerek toplumun maneviyatını bozmaması için gazetelere verilmemişti. Ondan sonra diğer esirler de sıkıntılarını, ıztıraplarını ve içinde bulundukları kötü durumu anlatmak için Seraskerlik makamına bir telgraf çekmeye teşebbüs etmişler. Fakat oradaki Osmanlı Devleti temsilcileri, Romanya hükümet yetkilileri nezdinde teşebbüse geçerek bu telgrafin çekilmesini engellemişlerdir. Esirlerin masrafları, iflas etmiş Osmanlı bütçesine zor gelecek bir meblağdı. Romanya'nın iddiasına göre esirler için sarf edilen meblağ 1 Temmuz 1878 tarihine kadar 1.210.000 franga ulaşmıştı. ${ }^{55}$

Bükreş'te özel görevle bulunan Süleyman Paşa ve Azaryan Efendi tarafindan Sadarete gönderilen 23 Temmuz 1878 tarihli tahrirat ve Plevne esirleri tarafindan Seraskerlik makamına gönderilmek istenen telgrafin sureti, BOA, Y. PRK. A, 1-114. Tercüman-ı Hakikat, Numara: 9, 6 Temmuz 1878/6 Receb 1295.

55 Bükreş’te özel görevle bulunan Süleyman Paşa ve Azaryan Efendi tarafindan Sadarete gönderilen
23 Temmuz 1878 tarihli tahrirat ve Plevne esirleri tarafindan Seraskerlik makamına gönderilmek
istenen telgrafin sureti, BOA, $\Upsilon$. PRK. A, 1-114. 
Esir değişimi mukavelesinin hazırlanmasına karar verilip, taraflar müzakereye başlamıştı. Gündeme gelen ilk konu esirlerin yol masrafları ve kaldıkları süre zarfinda harcanan meblağın Osmanlı Devleti tarafindan karşılanmasıydı. Ancak bunun için Romanya tarafindan yapılan hesaplamaların Bâbıâli temsilcileri tarafindan da kontrol edilerek kabul edilmesi gerekiyordu. Bu durum ise müzakereleri uzatmaktaydı. Oysa uzun bir süre perişan bir hayat süren esirler, evlerine dönmek için sabırsızlanıyorlardı. Dayanma gücü kalmayan esirler, bu durumdan dolayı karamsarlığga düşmüşlerdi. ${ }^{56}$

Müzakereler neticesinde bir mukavele hazırlanmıştı. Buna göre; mukavelenin imzalanmasının ardından esir değişimi yapılacaktı. Esirlere yapılan masraflar iki kısma ayrılacak olup, birincisi esir oldukları günden savaşın bitimine kadar ve ikincisi savaşın bitiminden itibaren ülkelerine iade edilene değin yapılan masraflardı. Bâbıâli, ödemeleri her biri altı ayda bir olmak koşuluyla on dört eşit taksitte, yani yedi sene zarfında tamamen yapmış olacaktı. Bu masrafların bir kısmını karş1lamak için, Bâbıâli, Vidin veyahut Tuna'nın sair kalelerinde bulunup kendisine lüzumu olmayan silah ve mühimmatı bu mukavelenin değişimini müteakip Romanya hükümetine terk edeceğini taahhüt edecekti. Bahsi geçen silahların kıymeti iki hükümetin de uygun bulduğu muhammenler tarafindan takdir olunacaktı. Mukavele tasdik ve imza olunduktan sonra on beş gün içinde teati edilecekti. İki taraf temsilcileri sözlü olarak tasdik ettikleri bu mukaveleyi imza edecekler ve armalı mühürleriyle mühürleyeceklerdi. ${ }^{57}$

Sultan Abdülhamid, bu mukavelede gündeme gelen Vidin veyahut Tuna'nın sair kalelerinde bulunup esirlerin masraflarına karşılık olmak üzere terki istenen silah ve mühimmatın Romanya'ya bırakılması maddesine itiraz etmişti. Çünkü buradaki silah ve mühimmatın ne cins ve çeşit olduğu tespit edilmemişti. Sultan, bu kalelerdeki silah ve mühimmatın her daim Osmanlı Devleti'ne lazım olacağını yönünde Sadareti uyarmıştı. ${ }^{58}$ Sultan Abdülhamid'in uyarısı üzerine Seraskerlik makamı tarafindan oluşturulan bir komisyon, bölgedeki savaş gereçlerinin listesini tutmakla görevlendirildi. Ancak Türk esirlerinin bu süre zarfinda Bükreş’te kalmaları onların durumunu daha perişan bir hale getireceği gibi onlar için harcanan

56 Saltanat-ı Seniyye ile Romanya Hükümeti arasında yapılan görüşmeler neticesinde hazırlanan mukavelename, BOA, I. HR, 277-16906.

57 Saltanat-ı Seniyye ile Romanya Hükümeti arasında yapılan görüşmeler neticesinde hazırlanan mukavelename, BOA, I. HR, 277-16906.

5821 Receb 1295 (21 Temmuz 1878) tarihli Sultan Abdülhamid'in iradesi, BOA, I. HR, 277-16906. 
meblağın da günden güne artmasına sebep olacaktı. Bu sebeple listeler oluşturulmadan önce esirlerin değişimi mukavelesinin bir an önce sonuçlandırılması gerekmekteydi. Sultan Abdülhamid'in de bunu uygun görmesi ile Romanya ile esir değişimi konusu tekrar müzakereye başlanmıştı. ${ }^{59}$

Bu sırada Bâbıâli temsilcileri tarafindan Vidin, Rusçuk, Silistre vs. Tuna kalelerinde bulunan daha önce Amerika ve Avrupa'dan satın alınan silahların listesi hazırlanmıştı. Bu silahların İstanbul'a getirilmesinin daha masraflı olacağını düşünen temsilciler, silahların Romanya'ya bırakılmasından yanaydı. Ancak Bâbıâli, çalışmalara şaibe karışmaması için oluşturulan komisyonun işe yarayan ve yaramayan silahlar diye hazırladığı listeden sonra uygun bulunanların Sultan Abdülhamid'in emriyle Romanya'ya teslim edilmesi gerektiğini düşünüyordu. ${ }^{60}$

Bâbıâli ile Romanya hükümeti arasında yapılan pazarlık neticesinde, savaşın bitiminden iadelerine kadar esirler için sarf edilen masraflara karşılık olmak üzere Romanya hükümeti Mayıs 1878'de 1.150.000 frank beyan etmiş, ancak bu meblağ günden güne artmıştı. ${ }^{61}$ Rakam 30 Haziran itibariyle 1.210 .000 frank olmuştu. ${ }^{62}$ Öyle gözükmektedir ki tutar günden güne de artacaktır. Savaş tazminatından dolayı zor durumda olan Osmanlı Devleti’nin malî yükünün daha fazla artmaması için bir an önce mukavelenin imzalanması gerekiyordu. Ayrıca esirlerin de dayanacak gücü kalmamıştı.

Yapılan görüşme ve müzakereler neticesinde esir düştükleri tarihten (10 Aralık 1877) mukavelenin hazırlandığı tarih olan 13 Ekim 1878 tarihine kadar esirler için yapılan harcamanın 863.482 frank 65 santim olduğu tasdik edildi. Esirlerin Kalas şehrine kadar nakilleri de dâhil olmak üzere mukavelenin imzalanmasından Osmanlı Devleti'ne iadesine kadar yapılacak olan masrafin da 560.000 frank olacağı hususunda karara varılmıştı. Yani esirler için Romanya hükümetine toplamda 1.423.482 frank 65 santim ödeme yapılacaktı. ${ }^{63}$

İlk kısımdaki meblağ mukavelenin imzalanmasından başlamak üzere her biri altı

5923 Şaban 1295 (22 Ağustos 1878) tarihli irade-i seniyye, BOA, I. DH, 773-62926.

606 Şaban 1295 (5 Ağustos 1878) tarihli irade-i seniyye, BOA, I. DH. 772-62866.

61 Süleyman Paşa ve Azaryan Efendi tarafindan Seraskerlik makamına Bükreş’ten çekilen 22 Mayıs 1878 tarihli telgraf, BOA, HR. TO, 555-71.

62 Süleyman Paşa'nın Bükreş’ten Seraskerlik makamına gönderdiği 11 Temmuz 1294 (23 Temmuz 1878) tarihli tahriratı, BOA, I. DH, 772-62866.

63 Osmanlı Devleti ile Romanya hükümeti arasında imzalanan mukavelenin tercümesi, $B O A, H R$. TO, 476-20; BOA, Y. EE, 73-16. 
ay arayla 14 eşit taksitte yedi sene zarfinda ödenecekti. ${ }^{64}$ İkinci kısımdaki 560.000 frankın üçte ikisi üç ay içerisinde ödenecekti. Üçte biri (yaklaşık 180.000 frank) ise Vidin Kalesi ve Tuna boyunda bulunan kalelerdeki silah ve mühimmatın Rumenlere bırakılmasıyla karşılanacaktı. Eğger Rumenlere bırakılan silah ve mühimmat, üçte birlik rakamı karşılamaz ise kalan tutar üç ay içerisinde Rumenlere ödenecekti. ${ }^{65}$ Vidin Kalesi veya Tuna boyundaki kalelerdeki, Osmanlı Devleti açısından gereksiz addedilecek olan eski silah, top ve mühimmatın Romanya'ya terk edileceğine dair madde, mukaveleye gizli madde olarak eklenmişti. ${ }^{66}$ Ancak madde hakkında bilgi sahibi olan Avrupa basını konuyu sayfalarına taşıyınca, bunları yakından takip eden Osmanlı basını da meseleden haberdar olmuştu. Osmanlı basını meseleyi sütunlarına taşısa da çıkan haberleri uydurma olarak nitelendirmişti. ${ }^{67}$

Görüşmeler devam ederken Romanya hükümeti, öncelikli olarak hasta olan Osmanlı esirlerine ülkelerine dönmeleri için müsaade etmişti. Bu esirler peyderpey Bükreş'ten ayrılmaktaydı. 24 Ağustos'ta iki cerrah ile iki subayın refakat ettiği 96 kişilik ilk kafile Kalas şehrine sevk edilmişti. Bâbıâli, her Cuma Kalas'a uğrayan Lloyd Vapur Şirketine, gelen bu askerleri İstanbul'a getirmesi yönünde talimat vermişti. 16 Eylül'de Kalas'tan İstanbul'a gitmek için vapur bekleyen esir sayısı 500'e yaklaşmıştı. ${ }^{68} 18$ Ekim'de 382 esir Kalas'tan İstanbul'a gönderilmişti. Aynı tarihte Romanya'da kalan esir sayısı 12 subay, 950 askerdi. ${ }^{69}$ Bâbiâli bu esirlerin sevki sırasında sarf edilmesi için daha önceki 200 liraya ilaveten Süleyman Paşa’ya 100 lira daha göndermişti. ${ }^{70}$ Romanya hükümeti kalan yaklaşık 1.000 esirin mukavele imzalanmadıkça salıverilmeyeceğini beyan etmişti. ${ }^{71} 31$ Ekim’e gelindiğinde

6427 Zilkade 1295 (22 Kasim 1878) tarihli tezkire-i samiye, BOA, I. HR, 278-17011.

65 Süleyman Paşa ve Azaryan Efendi tarafindan Sadarete Bükreş’ten çekilen 16 Eylül 1878 tarihli telgraf, BOA, HR. TO, 555-109; BOA, I. DH, 772-62866; Süleyman Paşa ve Azaryan Efendi tarafindan Hariciye Nezaretine çekilen 5 Aralı 1878 tarihli telgraf, BOA, HR. TO, 476-20; BOA, HR. TO, 555-86; BOA, I. DH, 772-62866.

66 Savaş esirlerinin mübadelesi hakkında Osmanlı Devleti ile Romanya hükümeti arasında imzalanacak mukavele layihası, BOA, HR. TO, 476-5; BOA, I. DH, 772-62866.

67 Vakit gazetesinin bu nitelemesinde muhafazakâr ve hükümet yanlısı oluşunun etkisi vardır. Vakit, Numara: 1059, 2 Ekim 1878/5 Şevval 1295.

68 Hariciye Nezaretinden Seraskerlik makamına gönderilen 25 Şaban 1295 (24 Ağustos 1878) ve 19 Ramazan 1295 (16 Eylül 1878) tarihli tezkireler, BOA, HR. SYS, 1235-48; BOA, HR. SYS, 123562.

69 Süleyman Paşa’nın Sadarete gönderdiği 6 Teşrin-i Evvel 1294 (18 Ekim 1878) tarihli tahrirat, BOA, HR. SYS, 1235-62.

7021 Ramazan 1295 (18 Eylül 1878) tarihli irade-i seniyye, BOA, I. HR, 277-16959.

71 Süleyman Paşa ve Azaryan Efendi tarafından 11 Ekim 1878 tarihinde Bükreş’ten Hariciye Neza- 
hem Rusya hem de Romanya'daki esaret hayatı sonlanıp memleketlerine gönderilen asker sayısı yaklaşık 35.000 'e ulaşmıştı. ${ }^{72}$

Esirler, ülkelerine döndükten sonra da talihsizlik peşlerini bırakmamıştı. Esaretten dönen 500 kadar esiri İstanbul'dan İzmir'e götüren İngiliz vapuru, Marmara'da başka bir İngiliz posta vapuruna çarpmıştı. Olay neticesinde posta vapuru batmış, askerleri İzmir'e götüren vapur ise baş tarafindan ağır darbe aldığı için tersaneye götürülmüştü. Olay neticesinde hayatını kaybeden kimse olmamıştı. ${ }^{73}$ Ülkelerine dönen mağrur esirler, sokaklarda, pazarlarda sefil ve pejmürde bir halde dolaşmaktaydılar. Bu durumdan haberdar olan Sultan Abdülhamid esirlerin geldikçe güzel bir şekilde giydirilmesini emretmişti. ${ }^{74}$

Esirlerin iadesi için hazırlanan mukavele Romanya Dışişleri Bakanına tebliğ edildikten sonra Bakan, bir noktaya itiraz etmişti. Mukavelenin üzerinde SaltanatSeniyye ve Romanya Hükümeti tabirleri bulunmaktaydı, lakin Bakan imzalanacak olan mukavelede "Zat-1 Hazret-i Padişahî" ve "Fehametli Romanya Prensi" denilmesini ${ }^{75}$ ayrıca bunların altında Hariciye Nazırı isimlerinin yabancı devletler ile imzalanan mukavelelerde olduğu gibi bu mukavelede de yer almasını talep etti. Bu talep sadece masrafların karşılanması için hazırlanan mukavelede değil aynı zamanda esir değişimi mukavelesinde de geçerli olacaktı. ${ }^{76}$ Anlaşılacağı üzere Romanya açısından buradaki önemli nokta yapılan masrafları karşılamaktan daha ziyade yeni kurulan devletlerinin Osmanlı Devleti tarafindan eşit statüde tanınmasiydi.

Esirler, mukavele imzalandıktan sonra sevk edilecekti. Bunların tamamının bir anda sevk edilmesi mümkün gözükmemekteydi. Kısım kısım sevk edilmeleri durumunda da mukavelede karşılanması taahhüt edilmeyen yeni harcamalar ortaya çıkacaktı. Bu sebeple Romanya hükümeti, esirlerin tamamının gitmesinden sonra yapılacak hesaplama neticesinde iaşe bedelinin tam olarak kapatılabileceğini ifade

reti çekilen telgraf, BOA, HR. SYS, 1235-67.

72 Tercüman-ı Hakikat, Numara: 107, 31 Ekim 1878/4 Zilkade 1295.

73 Vakit, Numara: 1065, 8 Ekim 1878/11 Şevval 1295.

74 BOA, Y. EE, 42-233.

75 Bükreş'te bulunan Osmanlı temsilcileri Süleyman Paşa ve Azaryan Efendi tarafindan Sadarete çekilen 10 Temmuz 1878 tarihli telgraf, BOA, HR. TO, 555-86.

76 Bükreş’te bulunan Osmanlı Devleti temsilcileri Süleyman Paşa ve Azaryan Efendi tarafindan Hariciye Nezaretine gönderilen 5 Kânun-1 evvel 1878 tarihli arizanın tercümesi, BOA, 1. A. RES, 2-6. 
etmişti. Yapılan ilk planda; esirler demir yolu aracilığıyla Varna'ya getirilecekti. Varna'dan sonraki yolculuk esnasında askerlerin sağlık durumu ile ilgilenecek birkaç askerî tabip ve eczacı bulundurulacaktı. Bahriye Nezareti tarafindan Varna'ya gönderilecek birkaç vapur ile de askerler İstanbul'a sevk edilecekti. ${ }^{77}$

Bu mukaveleye Osmanlı Devleti adına Mirliva Süleyman Paşa ile Bâbıâli memurlarından Azaryan Efendi; Romanya Devleti adına ise Bükreş Merkez Komutanı Albay Alexander Bodisteano, Harbiye Nezareti Müdürü ve Muhasebeci Vekili temsilci olarak katılmışlardır. ${ }^{78}$

Bu mukavelenin asıl suretine Hariciye Nazırı Safvet Paşa ile Romanya Senatosu Reis Vekili Beratyanoyu imza koymuştu. Mukavelenin son şeklinde, ikinci kısımdaki masraflar, Vidin veyahut Tuna'nın sair kalelerinde bulunup iki tarafin tayin edeceği uzmanlar tarafindan bir kıymet belirlenecek olan eski savaş aletlerinin verilmesiyle karşlanacaktı. Mukavelenin dördüncü maddesinde savaş aletlerinin teslim olunmasıyla esirlerin iadesine başlanacaktı. Beşinci maddeye göre mukavele, Osmanlı Padişahı ile Fehametlü Romanya Prensi hazretleri tarafindan tasdik olunacak ve imza olunduktan sonra 15 gün zarfinda ve mümkün ise daha önce, mukavele metinleri karşlıklı değiştirilecekti. ${ }^{79}$ Rumen tarafi esirlere sarf edilen meblağın dökümünü Osmanlı Devleti temsilcilerine teslim etmişti. ${ }^{80}$

Esirlerin değişim mukavelesi 5 Aralık 1878 tarihinde Bükreş'te tanzim edilmişti. ${ }^{81}$ Bu mukavele 16 Aralık'ta Romanya Millet Meclisi tarafindan onaylanmıştı. ${ }^{82}$ Esir-

7719 Rebiyülevvel 1295 (23 Mart 1878) tarihli sadaret tezkiresi ve 20 Rebiyülevvel 1295 (24 Mart 1878) tarihli irade-i seniyye, BOA, I. HR, 276-16812.

78 Osmanlı Devleti ile Romanya hükümeti arasında imzalanan mukavelenamenin tercümesi, BOA, HR. TO, 476-20.

79 BOA, Y. EE, 41-142.

80 Osmanlı Devleti ile Romanya temsilcileri arasında 24 Kânun-ı evvel 1879 (24 Aralık 1879) tarihinde yapılan toplantı tutanağının tercümesi ve Romanya Siyasiye Nezareti tarafindan tanzim edilmiş olup 1 Teşrin-i sani-11 Kânun-ı evvel 1878 tarihleri arasında Osmanlı esirleri için sarf edilen meblağı gösterir tablonun tercümesi, BOA, HR. TO, 521-30.

81 BOA, Y. EE, 73-16; Osmanlı Devleti ile Romanya Hükümeti arasında imzalanan mukavelenin tercümesi, BOA, HR. TO, 476-20; Mukavelenin girişinde Sultan II. Abdülhamid adına şu ibareler yer almaktaydı; Biz ki bi lütful-mevali Türkistan ve şamil olduğu memalik ve büldanın padişahı es-Sultan ibn-i Sultanü's-Sultanü'l-Gazi Abdülhamid Han ibnü's-Sultanü'l-Gazi Abdülmecid Han ibnü's-Sultanü'l-Gazi Mahmud Han'ız. İş bu tasdikname-i hümayunumuzla beyan ve ilan ederiz ki. BOA, $A$. DVN. $\mathcal{N} M H, 25-12$; Osmanlı Devleti ile Romanya Hükümeti arasında imzalanan mukavelenin tercümesi, BOA, Y. A. RES, 2-6; BOA, Y.EE, 41-142; Vakit, Numara: 1125, 8 Aralık 1878/13 Zilhicce 1295.

82 Vakit, Numara: 1135, 18 Aralık 1878/23 Zilhicce 1295. 
lere sarf edilen masrafların yer aldığı mazbata ise 26 Aralık 1878 tarihli iki nüsha olarak hazırlanmıştı. Romanya'dan Osmanlı Devleti'ne iade edilen Osmanlı esirlerinin 428'i subay, 5.512'si nefer olmak üzere 5.940 kişiden ibaretti. Bunların dışında temsilcilerin Bükreş'e gelmelerinden önce 26 ve 31 Mart’ta 12 subay ve 8 nefer olmak üzere 20 kişinin Osmanlı topraklarına gitmelerine müsaade edilmişti. Yine 28 Mart'ta Rahova esirlerinden 15 neferin daha ülkesine gitmesine izin verilmişti. Yani toplam olarak 440 subay ve 5.535 asker olmak üzere 5.975 kişi Osmanlı Devleti'ne iade edilmişti. Bunların dışında Bükreş Hastanesi'nde tedavi edilen 2 asker ile trene yetişemeyerek Romanya'da kalan 4 askerin dahi yakın bir zamanda iade edilmesine karar verilmiştir.

Hayatta kalanların dışında Romanya hastanelerinde vefat eden 1.474 Türk askerinin isimlerini ihtiva eden bir defter de Romanya yetkilileri tarafindan Osmanlı temsilcilerine verilmişti. ${ }^{83}$ Esirlerin değişimi ile ilgili mukavele imzalanmasından sonra dahi Bükreş’te hâlâ Osmanlı esiri bulunmaktaydı. Bükreş’te bulunan Osmanlı esirlerini ender olarak sütunlarına taşıyan Tercüman-1 Hakikat ve Vakit gazeteleri, kışın yaklaşmasından dolayı Bükreş’te bulunan Osmanlı esirlerine yeteri kadar kışlık elbise gönderildiğini haber yapmıştı. Ayrıca esir değişim mukavelesinin imzalandığını ve birkaç güne kadar Osmanlı esirlerinin İstanbul'a ulaşacaklarını haber vererek, yakınları esir düşenlerin gönüllerine su serpiyordu. ${ }^{84}$ Devrin iki büyük gazetesi olan Tercüman-1 Hakikat ve Vakit gazetelerinin Bükreş esirlerine karşı bu kadar duyarsız kalması, toplumda karamsar bir tablo oluşturmama kaygısından ileri geliyordu. Oysa Avrupa basınında Osmanlı esirlerinin yaşadığı ağır travma uzun uzadıya anlatılmaktaydı. Belki de Avrupa matbuatı bu haberler ile Osmanlı Devleti’nin acze düştüğünü tüm kamuoyuna göstermek niyetindeydi. Özellikle İngiliz matbuatı, Osmanlı esirlerini gravürler eşliğinde haber yapmaktaydı.

Osmanlı esirlerinin iadesi süreci tamamlanınca, Romanya Prensi Carol tarafindan bu hususta görevli olan Mirliva Süleyman Paşa'ya Akval de Romani nişanının Komandor rütbesi (üçüncü rütbeden Romanya yıldızı) ve Bükreş’te bulunan Hocabey Başşehbenderi Azaryan Efendi'ye de Akval de Romani nişanının Ofbiye rütbesi verilmişti. ${ }^{85}$

8324 Aralık 1878 tarihli toplantı tutanağı, BOA, HR. TO, 521-30.

84 Tercüman-ı Hakikat, Numara: 141, 13 Aralık 1878/18 Zilhicce 1295; Vakit, Numara: 1130, 13 Aralık 1878/18 Zilhicce 1295.

8521 Muharrem 1296 (15 Ocak 1879) tarihli irade-i seniyye, BOA, İ. HR, 335-21539; Azaryan 
Romanya hükümeti murahhaslar arasında akdedilen mukavelenin, bir an önce iki taraf devlet başkanlarınca imzalanıp değiştirilmesi için teşebbüste bulunmuştu. ${ }^{86}$ Bir sonuç alamayınca da 18 Mart 1879'da, esir değişim mukavelesinin onaylanan suretinin Osmanlı Devleti tarafindan verilmediğini gerekçe göstererek Bükreş’te kalmış olan 5-6 Türk askerini bırakmamıştı. ${ }^{87}$ Bâbıâli mukaveleyi Sultan Abdülhamid'e tasdik ettirmede ağırdan almaktaydı. Çünkü Rusya ile imzalanan esir değişimi ile karşılaştıııldığında Romanya ile imzalanan mukavelede zararlı çıkılmıştı. Rusya ile imzalanan mukaveleye göre savaş esirlerinin masrafları hesaplanırken, ateşkes antlaşması ile Berlin Antlaşması'nın imzalandığı tarih arası dikkate alınmıştı. Oysa Romanya ile imzalanan esir değişimi mukavelesinde esirlerin Osmanlı Devleti'ne iadesine kadar geçen süredeki masrafları da hesaba katılmıştı. ${ }^{88}$

Berlin Antlaşması ile bağımsızlı̆̆ı tanınan Romanya'nın İstanbul büyükelçisi, 1 Kasım 1878'de İstanbul'a ulaşmıştı. ${ }^{89}$ Elçi, 19 Kasım'da Sultan Abdülhamid'in huzuruna çıkarak itimatnamesini takdim etmiş ve çalışmalarına başlamıştı. ${ }^{90}$ Aynı tarihlerde Bâblâli de Petersburg Sefareti müsteşarı Süleyman Bey’i Romanya'ya ortaelçi sıfatıyla tayin etmişti. ${ }^{11}$ Süleyman Efendi, 16 Aralık 1878'de Prens Carol'un huzuruna çıkarak itimatnamesini takdim etmişti. ${ }^{92}$ Bu sayede iki ülke arasında diplomatik ilişkiler elçilik statüsünde de başlamıştı.

Romanya esirlerin iadesi antlaşmasını önemsiyor ve Osmanlı Sultanı tarafindan onaylanan mukavele metninin bir an önce kendilerine ulaşmasını, esirlerin bırakılması için şart koşuyordu. ${ }^{93}$ Nisan ayında Romanya Prensi Carol tarafindan im-

Efendi, 1 Ekim 1878'de Hocabey Başşehbenderliğine atanmışt, Vakit, Numara: 1059, 2 Ekim 1878/5 Şevval 1295.

8626 Zilhicce 1295 (21 Aralık 1878) tarihli tezkire, BOA, I. DH, 778-63332; 19 Safer 1296 (12 Şubat 1879) tarihli Sadaret Tezkiresi, BOA, Y. A. RES, 2-17.

87 Osmanlı Devleti’nin Bükreş Sefiri tarafindan Hariciye Nezaretine çekilen 18 Mart 1879 tarihli telgraf, BOA, HR. TO, 131-90; Hariciye Nazırının 25 Rebiyülahır 1296 (18 Nisan 1879) tarihli tezkiresi, BOA, I. HR, 279-17136; BOA, İ. HR, 335-21539.

8823 Rebiyülahır 1296 (16 Nisan 1879) tarihli Meclis-i Vükela mazbatası, BOA, Y. A. RES, 2-55.

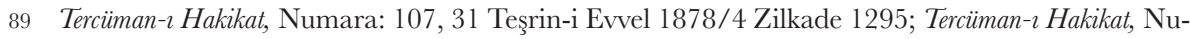
mara: 109, 2 Kasım 1878/9 Zilkade 1295.

90 Tercüman-ı Hakikat, Numara 123, 19 Kasım 1878/23 Zilkade 1295.

91 Tercüman-ı Hakikat, Numara: 124, 20 Kasım 1878/24 Zilkade 1295.

92 Vakit, Numara: 1135, 18 Aralık 1878/23 Zilhicce 1295.

93 Osmanlı Devleti'nin Bükreş Sefiri tarafindan Hariciye Nezaretine çekilen 18 Mart 1879 tarihli telgraf, BOA, HR. TO, 131-90; Hariciye Nazırını 25 Rebiyülahır 1296 (18 Nisan 1879) tarihli tezkiresi, BOA, İ. HR, 279-17136; BOA, İ. HR, 335-21539. 
zalanan suret Osmanlı temsilcilerine verilmişti. Bâbıâli ise Sultan Abdülhamid tarafindan imzalanan mukavele metnini, ancak 15 Haziran 1879 tarihinde Romanya'ya göndermişti. ${ }^{94}$ Romanya hükümetine ödemeler de bu tarihten sonra devam etmişti. ${ }^{95}$

Romanya hükümeti bu mukavelenin imzalanması sürecinde emeği olan Osmanlı temsilcilerine verdiği nişanlara mukabil kendi temsilcilerine de Bâbiâli tarafindan nişan verilmesini arzulamaktaydı. Bu ikili ilişkilerin güçlenmesi açısından da önemliydi. Bâbrâli durumdan haberdar olunca bahsi geçen kişilere nişan vermek için teşebbüse geçmişti. ${ }^{96}$

Bu mukavelenin Sultan Abdülhamid tarafindan onaylanmış bir suretinin Rumenlere gönderilmesinden kısa bir süre önce Romanya, İstanbul'a yeni bir elçi tayin etmiş ve diplomatik ilişkiler ileri bir noktaya taşınmıştı. Romanya elçisi 11 Nisan 1879 tarihinde Sultan Abdülhamid tarafindan kabul edilmişti. ${ }^{97}$

Mukavelenin imzalanmasına ve esirlerin iade edilmiş olmasına rağmen hâlâ Romanya'ya esir düşen yakınlarına kavuşamayan kimseler de vardı. Bunlardan biri 1881 yılı olmasına rağmen Plevne'de savaşan oğlundan haber alamayan Hasan Süleyman'dı. Hasan Süleyman, oğlu Mustafa'nın akıbetini öğrenmek için girişimlerde bulunmuşsa da bir netice elde edememişti. ${ }^{98}$ Yakınına kavuşamayan bir diğer kişi de 2. Ordu'nun 4. Piyade Alayının 2. Taburu Tüfekçisi Beypazarlı Halil Ağa'nın eşiydi. Halil Ăga'nın eşi, kocasının hayat ve memâtından haber alamadığından bahisle kendisine bilgi verilmesini, değilse onun maaşından bir miktarının kendine tahsis edilmesini talep etmekteydi. Romanya'da yapılan bütün araştırmalara, hastane kayıtları ve sair kayıt defterlerinin incelenmesine rağmen Halil Ağga'dan haber alınamamıştı. Plevne'de esir düştükten sonra Romanya'da Kortomargoril Hastanesi'nde kaldığına dair malumat sahibi olan eşi, artık ondan haber alamamaktaydı. Yine benzer bir şekilde aynı alay ve taburda görevli Hüseyin

24 Cemaziyülahır 1296 (15 Haziran 1879) tarihli irade-i seniyye, BOA, A. DVN. $\mathcal{N} M H, 25-12$; Osmanlı Devleti’nin Bükreş Sefiri tarafindan Hariciye Nezaretine çekilen 28 Nisan 1879 tarihli telgraf, BOA, HR. TO, 39-7.

95 Maliye Nezareti tarafindan Hariciye Nezaretine gönderilen 29 Ramazan 1296 (16 Eylül 1879) tarihli tezkire, BOA, HR. TH, 32-87.

96 Osmanlı Devleti'nin Bükreş Sefiri Süleyman Paşa tarafından Hariciye Nezaretine gönderilen 6 Cemaziyülahır 1296 (28 Mayıs 1879) tarihli tahrirat, BOA, HR. SYS, 1235-88.

978 Nisan 1879 (15 Rebiyülahır 1296) tarihli irade-i seniyye, BOA, I. HR. 279-17114.

98 Hariciye Nezaretinin 25 Muharrem 1298 (28 Aralık 1880), Harbiye Nezaretinin 12 Safer 1298 (14 Ocak 1881) tarihli tezkireleri, BOA, A. MTZ (04), 18-27. 
Bey'in eşi de kocasının peşine düşmüş, fakat bir malumat sahibi olamamıştı. Verilen cevap "muhtemelen Romanya'da vefat ettiği" yönündeydi. ${ }^{99}$ Savaş sonrasında esir düşmüş kocalarından haber alamayan kadınlar çevrenin de baskısıyla başka erkeklerle nikâhlanmaya mecbur bırakılmaktaydılar. Asker eşlerine herhangi bir gerçekliği olmayan ifadelerle kocalarının şehit olduğu ve onlardan bir daha haber alınamayacağı telkin edilmekteydi. Yahut bu askerlerin ağızlarından sahte mektuplar yazan bir takım şahıslar bu mektupları eşlerinin ümitleri kesilsin diyerek muhtar ya da imamlara ulaştırıyorlardı. Muhtar ya da imamlar bu mektuplara istinaden hiçbir araştırma yapmadan asker eşlerinin başkalarına nikâhlanmasının yolunu açacak ilmühaberler vermekteydiler. Öyle anlaşıllyor ki ahali, Bâbıâli'nin esir görüşmelerini sürdürdüğünden ve esirlerin yakın zamanda salıverileceklerinden habersizdi. Bu sebeple Bâbuâli, savaşın hemen bitiminde, savaş mevkilerinde esir bulunan asker ve subayların eşlerinin başkalarına nikâhlanmasını yasaklamıştı. Resmi yazışmalar yapılmadan cepheye gitmiş olan bir askerin eşinin başkasına nikahlanmasına meydan vermiş her kim olursa ağır bir şekilde cezalandırılması kararlaştırılmıştır. Ancak mukavelenin imzalanıp esirlerin iadesinden sonra bu yasağın bir hükmü kalmamıştı. ${ }^{100}$ Kadınların başkaları ile nikahlanmak zorunda olmasının bir diğer sebebi de, yukarıdaki bir esir yakınının "onun maaşından bir miktarının kendine tahsis edilmesi” ifadesinden anlaşıldığı üzere geçim kaygısıydı. Devlet yetkilileri bu sorunun önüne geçebilmek için esarette olan veya şehit düşen asker ve subayların eş ve çocuklarına talep etmeleri durumunda maaş bağlanmasını karar altına almışlardı. ${ }^{101}$

Osmanlı Devleti, savaş nedeniyle yaşadığı sarsıntıyı atlattıktan sonra esirlere yardımcı olan, özveriyle tedavi etmeye çalışan Rumenleri unutmamıştı. İlk etapta 3. rütbeden Mecidî nişanı verilen Doktor Paçel, Doktor Teryand Afilisid ve Doktor Kalendiro'ya 7 Kasım 1878'de 4. rütbeden Mecidî nişanı verilmişti. ${ }^{102} 7$ Aralık'ta da Romanya hükümeti memurlarından Nikola’ya 2. rütbeden Mecidî nişanı verilmişti. ${ }^{103}$ Esirlerin iadesinden yaklaşık beş yıl sonra Osmanlı Devleti'nin Romanya'daki sefiri olan Süleyman Hurşid Bey'den Osmanlı esirlerinin Romanya'da bulundukları sırada bunlara iyi muamelede bulunan kişilerin isimlerini talep etmişti.

99 BOA, HR. SYS, 1060-4.

100 Şura-yı Devletin 5 Cemaziyülahır 1295 (6 Haziran 1878) tarihli müzekkiresi, BOA, ŞD, 611-3.

10113 Zilkade 1294 (19 Kasım 1877) tarihli Dar-1 Şura-yı Askerî kararı, 22 Zilkade 1294 (28 Kasım 1877), tarihli irade-i seniyye, BOA, I. DH, 759-61928.

10212 Zilkade 1295 (7 Kasim 1878) tarihli irade-i seniyye, BOA, I. HR, 278-17004.

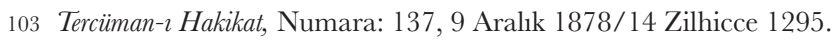


Süleyman Bey 2 Ocak 1883 tarihinde gönderdiği listede Başhekim Mösyö Fiyala'nın 3. dereceden Mecidî, Doktor Nikola Maldareskad, Doktor Dimitr Skdesve Rivalo, Doktor Pol Petrini'nin 4. dereceden Osmanî; Doktor Nikolaki Nibah, Doktor Kostantin İstirati, Doktor Dimitr Balano, Demir yolu Direktörü Lopolko, Demir yolu Müfettişi Baron Ronof, Pezpis'in 4. dereceden Mecidî; Doktor Mişel Terand Akidsakd, Doktor Teodor Terand Akidsakd, Doktor Papa Corc, Doktor, Mişel Corcisko, Doktor Goro Govar Vorcisko, Lekoziki Instasyivic, Kızılhaç Kâtibi Jan Bübük, Kızılhaç Kâtibi Nikola Kika, Bükreş’te Osmanlı tebaasından ve emlak sahibi olan Abdulvehab Ağa'nın ise 5. dereceden Mecidî nişanıyla taltif edilmeleri gerektiğini beyan etmiş, Sultan Abdülhamid de bunu uygun bulmuştu. ${ }^{104}$

\section{Sonuç}

93 Harbi’nde Romanya ve Osmanlı Devleti, Rusları kendilerine karşı tehdit olarak görmekteydiler. Buna rağmen her iki taraf, ortak düşmana karşı birlikte hareket edememiş ve savaştan zararlı çıkmışlardı. Osmanlı Devleti diplomatik bir hata yaparak Romanya'yı Rusya'ya mecbur bırakmıştı. Oysa Romanya ile Rusya'nın tarihî ve kültürel olarak anlaşması pek mümkün değildi. Romanya savaş öncesinde Osmanlı Devleti ile irtibat kurmak istemişse de bir sonuç elde edememişti. Sultan Abdülhamid'in idareyi tam olarak eline alamamış olması ve Bâbıâli'nin 1876 yılında yayınladığı meşrutiyet beyannamesinde Romanya’nın Osmanlı Devleti'ne tâbi muhtar bir eyalet olduğu yönündeki hükmü, Romanya’yı Osmanlı Devleti’nden uzaklaştırmıştı. Oysa Osmanlı Devleti başlangıçta Romanya’yı yanında tutmayı başarsaydı, Rusların güneye inmesi çok kolay olmayacaktı. Çünkü Romanya hükümeti, Rusların kendi topraklarından geçmesine pek de taraftar değildi. Buna rağmen Ruslara mahkûm olan Rumenler, istemeyerek de olsa Ruslarla ittifak yapmışlardı. Aslında onlar da savaşın sonucunu tam olarak okuyamamışlardı. Aksi olsaydı Besarabya'yı kaybedeceklerini tahmin etmeleri gerekirdi. Bu sebepledir ki Rumenler savaş sonrasında Rusya ile birleşmekten pişmanlık duyduklarını ifade etmişlerdi.

Plevne Müdafaası sırasında Rusların ilerlemesi durdurulmuşken Rumenlerin bu kritik anda Ruslara yaklaşı 50.000 kişilik bir ordu ile yardıma gelmesi savaşın seyrini değiştirmişti. Bu hamleden sonra Plevne, Rusların eline geçmiş ve Gazi Osman Paşa ile burada bulunan askerlerin tamamı Ruslara esir düşmüştü. Hadise, Osmanlı ordusunu ve ahalisini psikolojik olarak yıkıma uğratmış ve Ruslar, önlerine hiçbir engel çıkmadan Yeşilköy’e kadar ilerlemişlerdi.

1048 Rebiyülevvel 1300 (17 Ocak 1883) tarihli irade-i seniyye, BOA, I. HR, 288-18044. 
Plevne'de alınan esirlerin yaklaşı 30.000'i Rusya'ya, 10.000’i ise Romanya'nın başkenti Bükreş'e götürülmüş̧ü. Esirler büyük bir insanlık dramı yaşamışlar, birçoğu açlık, şiddetli soğuk ve salgın hastalıktan dolayı hayatını kaybetmişti. Yaşananlar o kadar vahimdi ki, esirlerin yaşadığ korkunç manzaralar Rumen ve Rus ressamlar tarafindan tuvale yansıtılmıştı. Aynı zamanda İngiliz savaş muhabirleri de gravürlerle bu elim manzaraları çizimlerine yansıtmışlardı.

1877 yllının sonlarına doğru esir düşen bu askerler sulh görüşmelerinin yapılmasından sonra Osmanl Devleti ile Romanya arasında yapılan antlaşma ile ancak 1878 yllının sonlarına doğru ülkelerine dönme firsatı bulmuşlardır. Neticede 440'ı subay ve 5.541'i er olmak üzere toplam 5.981 kişi Osmanlı Devleti'ne iade edilmişti. Hayatta kalanların dışında Romanya hastanelerinde vefat eden 1.478 Türk askerinin isimlerini ihtiva eden bir defter de Romanya yetkilileri tarafindan Osmanlı temsilcilerine verilmişti. Vefat eden askerlerin büyük bir kısmının nereye defnedildiği meçhuldür. Tespitlerimize göre bunlardan 33’ü Dealu Manastırı'na defnedilmiştir. Bir kısmının cenazesi yakılmıştır. Romanya'da bu esirlerin hatıralarını yâd eden, onları temsil eden hiçbir nişane bulunmamaktadır. Bu sebeple bu büyük dramın unutulmaması için esaret hayatı sırasında yaşamlarını kaybeden askerlerin anısına Türkiye Cumhuriyeti tarafından bir nişane yapılmalıdır.

Türk esirler, Romanya ahalisinde tesir bıraktıkları gibi sanatçıları da etkilemişti. Ünlü Rumen Ressam Nicolae Grigorescu (1838-1907)'nun Prizonieri Turci (Türk Esirler) ve Convoi de Prizonieri Turci (Türk Esirler Konvoyu) isimli tabloları bunun en güzel örnekleridir.

Romanya'daki Türk esirler; vakur, kendinden emin, onurlu duruşuyla Romanya halkında, siyasetçilerinde ve sanatçılarında derin izler bırakmıştı. Bu esirlerin değişim süreci iki devlet arasında diplomatik ilişkilerin hızlanmasına yol açmıstı. Romanya bu yolla kendisini Osmanlı Devleti’ne tanıttığı gibi Osmanlı Devleti de Rusya'ya karşı sınırında bir tampon bölge oluşturmuş oluyordu. Rumenler, Osmanlı Devleti ile yapacakları antlaşmayı bir firsat olarak görüyorlardı. Son olarak Rumenlerin esir düşen Türk askerlerine merhametli davranması da iki toplum arasında duygusal yakınlığ arttırmıştı. 


\section{KAYNAKLAR}

\section{Arşiv Kaynakları}

Türkiye Cumhuriyeti Cumhurbaşkanlığı Devlet Arşivleri Başkanlığı Osmanlı Arşivi (BOA)

Sadaret Divan (Beylikçi) Kalemi Name-i Hümayun Kismı Evrakı (A. DVN. NMH), 24-9; A. DVN. NMH, 25-12.

Sadaret Vilâyât-ı Mümtaze Kalemi Bulgaristan Evrakı (A. MTZ(04)), 18-27.

Hariciye Nezareti Siyasî Kalem Evraku (HR. SYS), 1-4; HR. SYS, 1060-4; HR. SYS, 123548; HR. SYS, 1235-62; HR. SYS, 1235-67; HR. SYS, 1235-88.

Hariciye Nezareti Tahrirat Kalemi Evraku (HR. TH), 32-87.

Hariciye Nezareti Tercüme Odası Evrakı (HR. TO), 39-7; HR. TO, 131-90; HR. TO, 374126; HR. TO, 476-5; HR. TO, 476-20; HR. TO, 521-30; HR. TO, 555-71; HR. TO, 555-86; HR. TO, 555-109.

Írade-i Dahiliyye (İ. DH), 759-61928; 766-62403; I. DH, 766-62444; I. DH, 76862565; I. DH, 769-62663; I. DH. 772-62866; I. DH, 773-62926; I. DH, 77863332.

Irade-i Hariciyye (İ. HR), 276-16812; I. HR, 277-16906; I. HR, 277-16959; I. HR, 278-17004; I. HR, 278-17011; I. HR. 279-17114; I. HR, 279-17136; I. HR, 288-18044; I. HR, 335-21539.

Şura-yı Devlet Evrakı (ŞD), 611-3.

Yıldız Evrakı Sadaret Resmî Maruzat (Y. A. RES), 2-6; Y. A. RES, 2-17; Y. A. RES, 2-55.

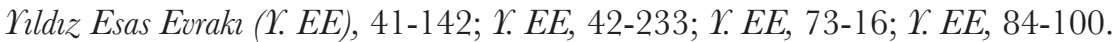

Yildız Perakende Sadaret Maruzatı Evrakı (1. PRK. A), 1-114.

Yildız Perakende Hariciye Nezareti Maruzatı Evrakı (1. PRK. HR), 2-53; Y. PRK. HR, 2-55.

\section{Süreli Yayınlar}

Tercüman-ı Hakikat

The Graphic

The Illustrated London News 
The Lancet

Vakit

\section{Araştırma ve İnceleme Eserler}

Barkley, Henry C, A Ride Through Asia Minor and Armenia, London 1891.

Birbudak, Togay Şeçkin, Romanya’nın Bağımsızhğını Kazanması, Gazi Üniversitesi Sosyal Bilimler Enstitüsü Yayınlanmamış Doktora Tezi, Ankara 2014.

Forbes, Archibald, Czar and Sultan, New York 1894.

Hülagü, M. Metin, Gazi Osman Paşa Yaralı Mareşal, İzmir 2006.

İbrahim Edhem, Plerne Hâtıralar, Yay. Haz: Seyfullah Esin, Tercüman 1001 Temel Eser, İstanbul 1979.

Karpat, Kemal H, Balkanlar'da Osmanh Mirası ve Ulusçuluk, Çev: Recep Boztemur, İmge Kitabevi, Ankara 2004.

Kurat, Yuluğ Tekin, "1877-78 Osmanl-Rus Harbinin Sebepleri”, Belleten, XXVI/103, Temmuz 1962.

Mahmud Celâleddin Paşa, Mir'at-ı Hakîkat II, (Haz: İ. Miroğlu, M. Derin, M. Halcoğlu, Ö. Akdaş), Tercüman 1001 Temel Eser, İstanbul 1980.

Manastırlı Mehmet Rıfat Bey, 93 Harbi Faciası, Haz: Tahsin Yıldırım, Dün Bugün Yarın Yayınları, İstanbul 2010.

Maxim, Mihai, "Romanya", Diyanet İslam Ansiklopedisi, c. XXXV, İstanbul 2008, s. 170 .

Ollier, Edmund, Cassell's Illustrated of the Russo-Turkish War, c. II, London 1890.

Özcan, Leyla, "Türk Kızılay Müessesesinin Milletlerarası Kızılhaç ile Olan Münasebetleri”, İstanbul Üniversitesi Hukuk Fakültesi Mecmuas, , S. 3-4, 1964, ss. 609653.

Reid, Stuart J, Memoirs of Sir Wemyss Reid 1842-1885, Outlook Verlag, Frankfurt 2018.

Sertoğlu, Midhat, Mufassal Osmanl Tarihi, c. VI, Türk Tarih Kurumu Yayınları, Ankara 2011.

Şahin, Turhan, Öncesi ve Sonrasiyla 93 Harbi, Kültür Bakanlığı Yayınları, Ankara 1988. 
Şapolyo, Enver Behnan, Türk-Rus Savaşlan Tarihi Gazi Osman Paşa ve Plevne Müdafaası, Türkiye Yayınevi, İstanbul 1959.

Uğuz, Sacit, Basiret Gazetesi’ne Göre 93 Harbi’nde Rumeli (1877-1878), Atatürk Üniversitesi Sosyal Bilimler Enstitüsü, Yayınlanmamış Yüksek Lisans Tezi, Erzurum 2003. 


\section{EKLER}
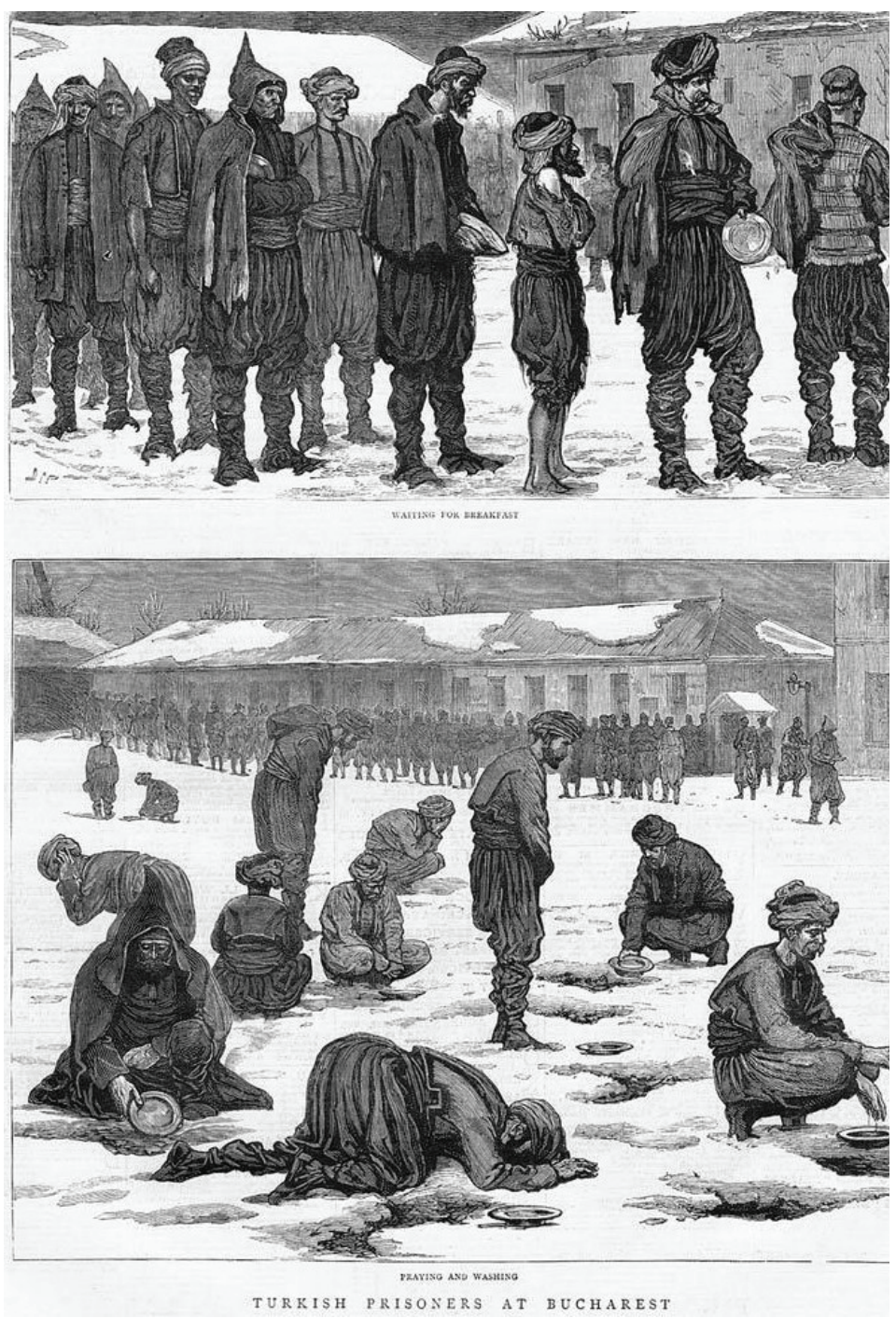

Ek 1: Bükreş’te Bulunan Türk Esirleri Tasvir Eden Gravürler (Kahvaltiyı Bekliyorlar, Namaz ve Abdest) ${ }^{105}$

105 Bükreş'te kahvaltı için bekleyen ve abdest alıp namaz kılan Türk esirler, The Graphic, Jan. 19, 1878; Benzer bir gravür için bakınız, Ollier, a.g.e., ss. 3-4. 


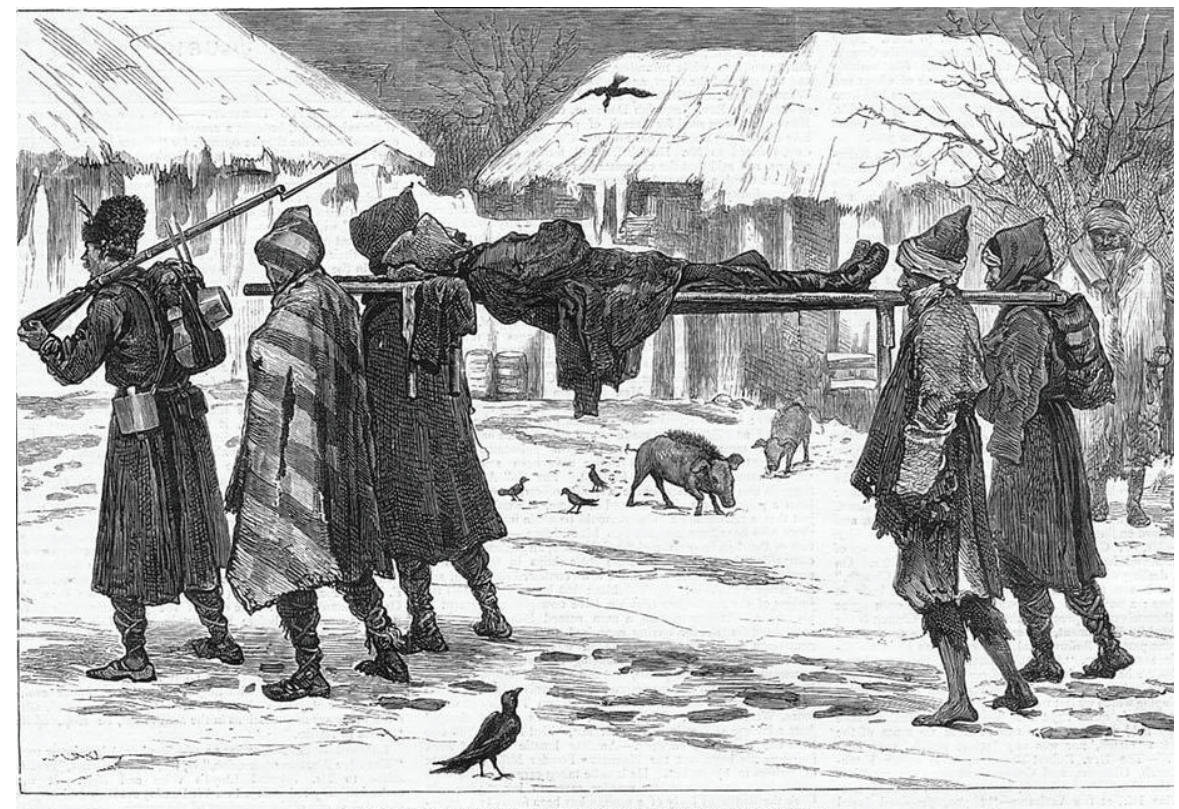

“'THE RELEASED CAPTIVE :' PRISONERS OF WAR BURYING THEIR OFFICER

Ek 2: "Serbest Tutsak": Komutanlarını Defneden Savaş Esirleri. ${ }^{106}$

106 The Graphic, Feb 9, 1878.

Belleten, Ağustos 2020, Gilt: 84/Sayı: 300; 789-824 


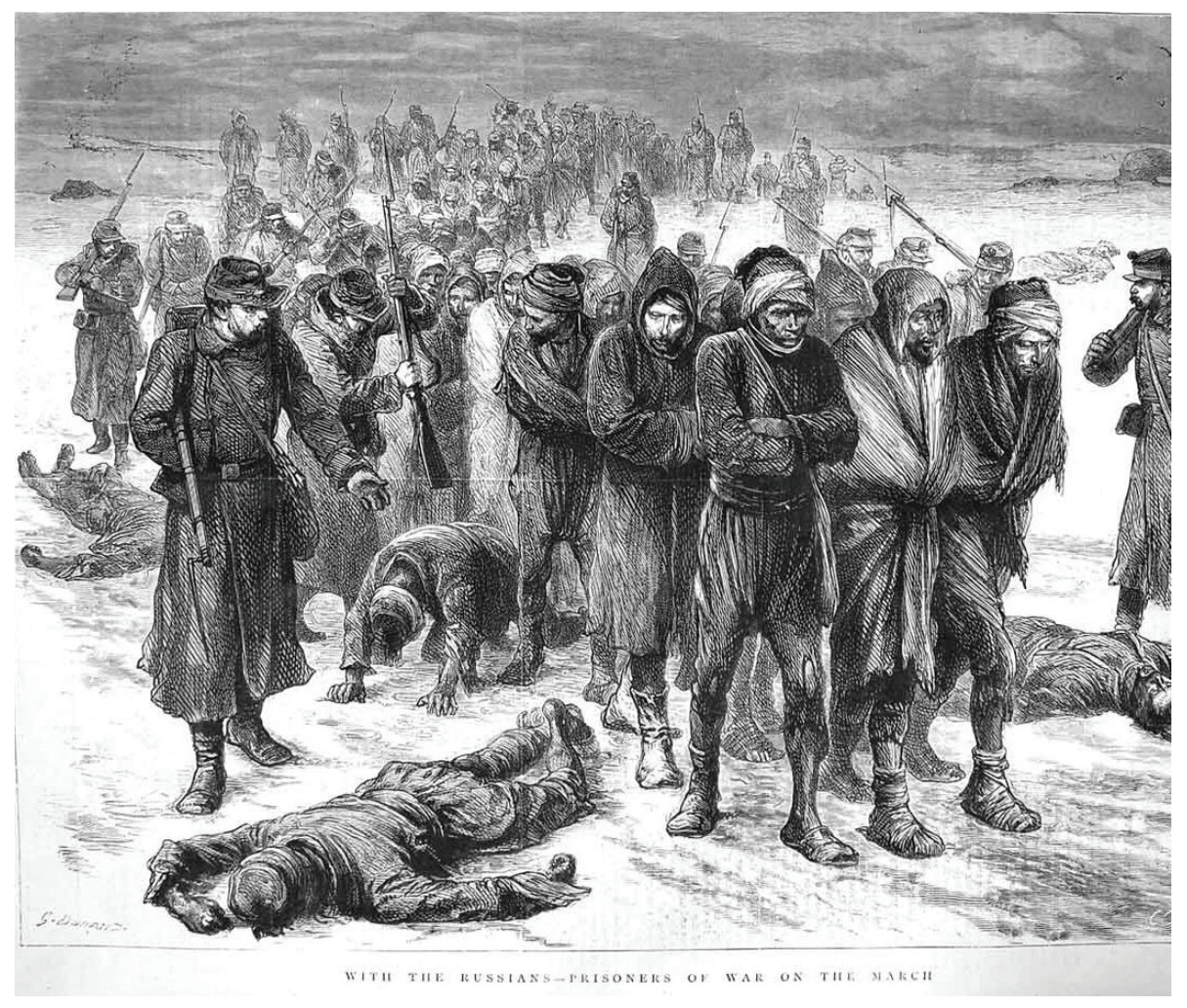

Ek 3: Rusların Denetiminde İlerleyen Savaş Esirleri ${ }^{107}$

107 The Graphic, Feb. 9, 1878. 


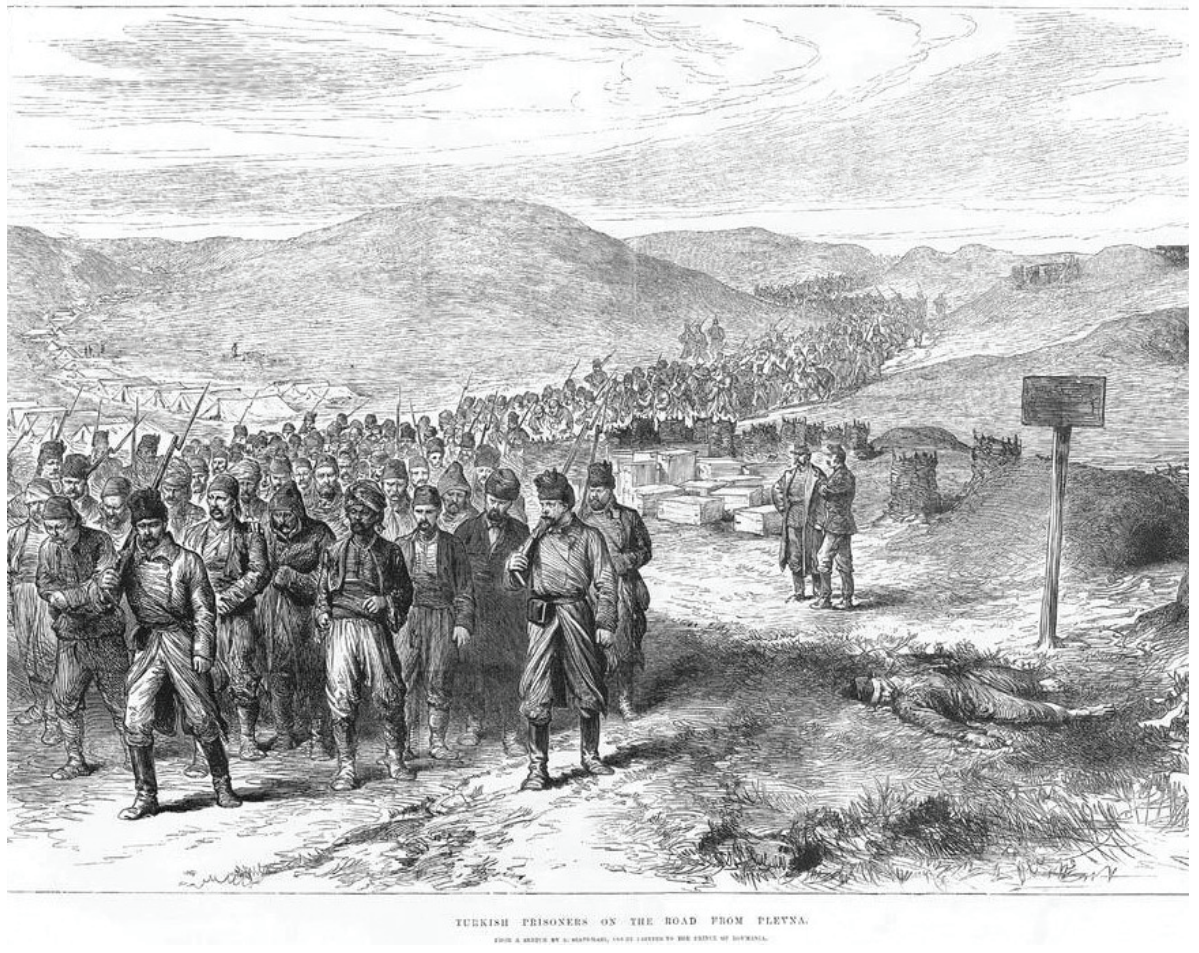

Ek 4: Plevne’den Götürülen Türk Esirleri ${ }^{108}$

108 The Illustrated London Neres, January 1878.

Belleten, Ağustos 2020, Cilt: 84/Sayı: 300; 789-824 